\title{
Current vegetation structure and composition of woody species in community-derived categories of land degradation in a semiarid rangeland in Kunene region, Namibia
}

\author{
Emilia N. Inman ${ }^{1,3}$ (1) | Richard J. Hobbs ${ }^{1} \quad$ | Zivanai Tsvuura ${ }^{2}$ | Leonie Valentine ${ }^{1}$
}

${ }^{1}$ School of Biological Sciences, The University of Western Australia, Crawley, Australia

${ }^{2}$ Centre for Functional Biodiversity, School of Life Sciences, University of KwaZulu-Natal, Scottsville, South Africa

${ }^{3}$ Multidisciplinary Research Centre, University of Namibia, Windhoek, Namibia

\section{Correspondence}

Emilia N. Inman, School of Biological Sciences, The University of Western Australia, 35 Stirling Highway, Crawley, WA 6009, Australia.

Email: haimbiliemilia@gmail.com

Funding information

World Wildlife Fund, Grant/Award Number: SZ43; University of Namibia

\begin{abstract}
Land degradation has put the world's rangelands under intense pressure and reduced their capacity to provide vital services to those who solely depend on them for survival. With the current pressures on rangelands, worldwide, there is an urgent need to survey the present condition of rangelands. Such detailed surveys can identify where improvement programmes can be emphasised; whether it be reseeding, stock control, sociological restraints or other actions. To combat rangeland degradation, management systems are more effective when they account for community perceptions and practices. This study aims to assess the current status of woody plants in different categories of degradation as perceived by herders in Kunene, Namibia. Furthermore, we wished to compare the perception of degradation by herders with the measured ecological condition. With the help of herders, sites representing different categories of degradation (low, moderate, high and protected) were identified and 10 plots of $400 \mathrm{~m}^{2}$ each were established in each category. Species diversity, density, basal area and regeneration of woody plants increased sequentially along the degradation gradient (high to low). Vegetation attributes such as species diversity, seedling density and standing basal area increased with increasing distances from the villages. Although the herders' perception of degradation, for high and moderate degradation, matches the ecological results, the low degradation sites show signs of bush encroachment, a type of degradation that the herders did not perceive as degradation. Colophospermum mopane, a known encroacher species across Namibia, was the dominant species in the moderate and low degradation sites. Pechuel-loeschea leubnitziae, which is also known to be an indicator of degradation, was the dominant species in the high degradation sites. The findings highlight the present and future threats the study area is facing and form the basis for current restoration research.
\end{abstract}

KEYWORDS

bush encroachment, community perception, land degradation, Namibia, vegetation structure

\section{1 | INTRODUCTION}

The land is a precious natural resource, and humans ultimately depend on it for their livelihoods and raw materials (Imeson, 2012). In many parts of the world the quality of the land is declining, thereby limiting its capacity to provide the manifold goods and services, which humanity depends on for survival (Caspari, van Lynden, \& Bai, 2015). One of 
the major threats to terrestrial ecosystems and ecosystem services is land degradation (Gomiero, 2016; Vogt et al., 2011).

Land degradation has been identified as one of the most pressing global problems (Stocking, 2001). Although land degradation is commonly considered in environmental protection and nature conservation and management, a precise definition has been lacking both in science and policy (Plesnik, Hosek, \& Condé, 2011). This is because land degradation is multifaceted, with varying definitions depending on the subject to be emphasised (Tesfa \& Mekuriaw, 2014). Generally, the term 'degradation' is taken to mean a loss of structure, productivity and native species diversity (Lamb \& Gilmour 2003). Land degradation is related to the loss of ecosystem services and is referred to as desertification when it occurs in drylands (Abdi, Glover, \& Luukkanen, 2013). Bush encroachment is also regarded as one of the most extensive forms of degradation in rangelands of arid and semiarid regions (Lukomska, Quaas, \& Baumgärtner, 2014; Reed et al., 2015). Poor grazing management strategies have often been cited as one of the major anthropogenic causes of bush encroachment (Lukomska et al., 2014). In many cases, land degradation leads to the removal of organic matter, and subsequently reduced soil health (Bhowmik et al., 2019). Poor soil health poses a threat to food security and has important repercussions on societies depending on land for their livelihoods (Gomiero, 2016).

Land degradation threatens the drylands of Sub-Saharan Africa more than any other region in the world (Darkoh, 1993), due to pressures from human and livestock populations, coupled with recurrent droughts (Abdi et al., 2013). Darkoh (1993) called it the "scourge of Africa". These drylands occupy the peripheries of the Sahara and the Kalahari Deserts, where the mean annual precipitation is low (100-600 mm), and human livelihood is based mainly on livestock and crop farming activities (United Nations Convention to Combat Desertification, 2009). The dominant land type in Southern Africa is rangeland, the primary use of which is livestock production (Hodgson, 1975). These rangelands represent some of the most degraded land-use types in the world (Papanastasis, 2009).

In Namibia, the most arid country in the south of the Sahara, $45 \%$ of the national land area can only be used as rangeland (Mendelsohn, 2003). Thus, many Namibians are pastoralists, whose livelihoods mainly depend on natural rangeland resources (Eisold, 2010). High variability of rainfall and distinct seasonal changes of the amount and quality of rangeland fodder resources are typical characteristics of the semi-arid and arid rangelands of Namibia (Schneiderat, 2011). Reduced vegetation cover and subsequent soil denudation can be found in many regions in Namibia, particularly in Erongo (in western Namibia), Kunene (in northwestern Namibia) and north-central regions (Seely \& Jacobson, 1994). Severe rangeland degradation and conflicts over rangeland use can create significant social, economic and environmental problems (Bedunah \& Angere, 2012).

Kunene is one of the worst drought-affected and most deprived regions in Namibia (National Planning Commission [NPC], 2015). It is characterised by rocky and bare mountains receiving low and unreliable rainfall, resulting in poor veld condition, with little ground cover. The resource base and, subsequently, the livelihood of crop and livestock farmers in this area have been significantly eroded and are likely to worsen further, should the drought conditions continue (Food and Agriculture Organization, 2016). At the household level, livestock provides food and income and is considered to be a "savings account", which provides a safety net in times of hardship (Food and Agriculture Organization, 2016). Kunene's tradition of livestock farming has been passed on from generation to generation, but it is no longer sustainable due to factors such as population increase and recurrent droughts. Despite persistent drought and increased human population, the same beliefs anchor the communities; "without livestock you are nothing". Livestock is the currency, and as they lose their livestock, they try to acquire more, though their land is no longer able to sustain more. In a situation like this, it becomes increasingly difficult to find a realistic solution that will benefit both the environment and people.

With the current pressures on rangelands in Namibia and worldwide, which eventually impact on the livelihoods of many people, it is crucial that something is done radically and urgently. One of the first needs is to survey the present condition of rangelands. Such detailed surveys can identify where improvement programs can be emphasised; whether it be reseeding, stock control, sociological restraints or other actions (Hodgson, 1975). Combating rangeland degradation and desertification requires an accurate assessment of the current status of land degradation and an evaluation of the potential magnitude of the degradation threat (Mahyou, Tychon, Balaghi, Louhaichi, \& Mimouni, 2016). It is, therefore, essential to have a consistent source of information relating to factors such as biomass, vegetation composition and diversity as well as cover. Knowledge of the patterns of vegetation dynamics provides an integrated response to previous ecological events, managerial prescriptions and presents a practical means to evaluate rangeland resources (Briske, Fuhlendorf, \& Smeins, 2005; Kacholi, 2014; Mishra et al., 2013).

To effectively combat rangeland degradation, rangeland management systems also need to integrate community perceptions and practices (Khwarae, 2006). Local-participation approaches assume that pastoralists' knowledge can supplement scientific knowledge concerning environmental assessment and conservation (Behmanesh, Barani, Abedi Sarvestani, Reza Shahraki, \& Sharafatmandrad, 2016). Understanding the differences between the perceptions of scientists and local communities can help bridge the gaps to bring about sustainable use of natural resources (Khwarae, 2006). One fundamental element in local environmental monitoring in rangelands is the perception and rating of local key forage species by the community members (Eisold, 2010; Niamir-Fuller, 1999). Pastoral communities have an elaborate knowledge of plant species composition and palatability to grazing animals, and trends in vegetation change in response to factors such as rainfall variability and grazing pressure (Behmanesh et al., 2016; Kgosikoma, Mojeremane, \& Harvie, 2012). Pastoral communities also have elaborate knowledge of medicinal uses of the indigenous plants and the types of diseases they treat (Otieno \& Analo, 2012; Rakotoarivelo et al., 2015). A key question in ethnobotany is why certain species are selected for a particular use instead of others (Soldati, de-Medeiros, Duque-Brasil, Coelho, \& Albuquerque, 2017). Different communities may have different 
perceptions and beliefs, as well as preferences (Van-der-Hoeven et al., 2013). Understanding the factors that influence the edifice of local knowledge about natural resources is vital for studies that investigate the local context of biodiversity management and conservation (Albuquerque et al. 2018).

In Kunene, trees and shrubs play an essential role in the livelihood system of the communities as they are a source of fodder, food, medicine and building materials (Integrated Environmental Consultants Namibia, 2011). Due to this dependence on woody species, the communities have accumulated extensive knowledge about individual woody species used for fodder and medicine. Under harsh conditions, the significance of plant utilisation for food and medicine increases (Kassam, Karamkhudoeva, Ruelle, \& Baumflek, 2010). Medicinal plants provide enormous opportunities for local communities' development and livelihood improvement (Cheikhyoussef, Mapaure, \& Shapi, 2011). Other natural resources, such as wild fruits and herbs, also make an essential contribution to the livelihoods of the people. Documenting pastoralists' ethnobotanical knowledge and perception of rangeland vegetation can provide context-specific recommendations for policies that will facilitate adaptation to woody encroachment. This will, in turn, enhance the resilience of human communities (Liao, Ruelle, \& Kassam, 2016). Recording indigenous knowledge of uses of species is, therefore, an important step in understanding the impacts of land-use and land cover change (Cummings \& Read, 2016; Jamsranjav, Fernández-Giménez, Reid, \& Adya, 2019). Indigenous knowledge is not only helpful in understanding the actual rangeland condition but may also encourage local participation for rangeland rehabilitation activities (Dabasso, Oba, \& Roba, 2012).

This type of knowledge and insight has a significant influence on the management strategies adopted to exploit a particular ecosystem (Eisold, 2010). It is, therefore, essential to understand how pastoralists perceive rangeland conditions and the extent of degradation in different types of rangelands. A common understanding between researchers and pastoral communities will help find practical solutions for combating rural poverty and environmental degradation (Kessler \& Stroosnijder, 2010). Understanding and evaluating the significance of land degradation from the farmers' perspective is, therefore, a crucial first step towards developing a response strategy to rural poverty and degradation (Kessler \& Stroosnijder, 2010).

The current study aims to record and describe the current status of vegetation in different categories of perceived degradation in Kunene Region, Namibia. We examined how woody species diversity, composition, structure and the demography of plant life-stages (seedlings, trees, etc.)-varied among land degradation categories. We also compared soil characteristics in different degradation categories and determined the relationships between vegetation parameters and distances from the centres of villages. Furthermore, we explored the uses associated with plants from the rangeland of Kunene region by community members. Finally, we compared the perception of degradation by community members with ecological results. We hypothesised that diversity, composition and regeneration potentials, as well as soil characteristics, would differ among different categories of degradation. This information can help inform rangeland conservation and management by providing baseline information on the present rangeland condition. Such information can pinpoint where improvement programs can be emphasised in terms of restoration, management or other actions. It will also help identify gaps in the local perception of rangeland degradation to help improve pastoralists' knowledge.

\section{2 | MATERIALS AND METHODS}

\subsection{Study area}

The field survey was conducted in Epupa Constituency, Kunene Region, Namibia (Figure 1). Kunene Region occupies the north-west corner of Namibia, bordering Angola in the north and the Atlantic Ocean in the west, with a land area of $115,260 \mathrm{~km}$. Kunene Region has a population of 86,856 people, of which 17,696 live in Epupa Constituency (NPC, 2015). Livestock production is one of the key sources of livelihood to many rural households in Kunene Region. Kunene has a shrubland-woodland mosaic vegetation structure (2002). Annual rainfall in Kunene is sporadic and increases from west to east from less than 50 to $415 \mathrm{~mm}$ (Integrated Environmental Consultants Namibia [IECN]). Summer day temperatures are often very hot, reaching up to $35^{\circ} \mathrm{C}$ with a minimum average temperature of $14^{\circ} \mathrm{C}$. Average winter temperatures range from 5 to $26^{\circ} \mathrm{C}$ (Kunene Regional Council, 2015). The most visible and readily felt impacts of climate change are perhaps the persistent dry spells and frequent droughts in this region. Farmers look forward to the rain every year, always on a lookout for available grazing land, but lack of rainfall has led to poor livestock condition and loss of animals (IECN, ). Kunene is one of the most heavily degraded regions in Namibia. Well-known causes, such as over-utilisation of the rangeland because of a high concentration of livestock, as well as continuous grazing and trampling by livestock were cited (NPC, 2015). For the past 10 years, average annual rainfall for the study area ranged between 12 and $30 \mathrm{~mm}$ (Morgan, Kunene River Lodge, personal communications, November 17, 2018). The inhabitants are the Himba people, a pastoral community farming with goats, sheep and cattle.

\subsection{Data collection}

Data were collected between September and October 2017. With the help of the herders, sites representing different categories of degradation were selected. This was done with 12 herders between the age of 27 and 68 who took part in drive transects to identify areas they thought were degraded, moderately degraded and not degraded. During these drives, herders (Table S1 and Figure S1) shared their perception of degradation and what they based their classification on. From these, three categories of land degradation (low, moderate and high) were identified. The drive transects were taken in four different directions from the centre of the village (Otjimuhaka) located $10 \mathrm{~km}$ west of Kunene river lodge (Figure S2). From the intersection located in Otjimuhaka village, we drove east towards Ruacana, west towards 


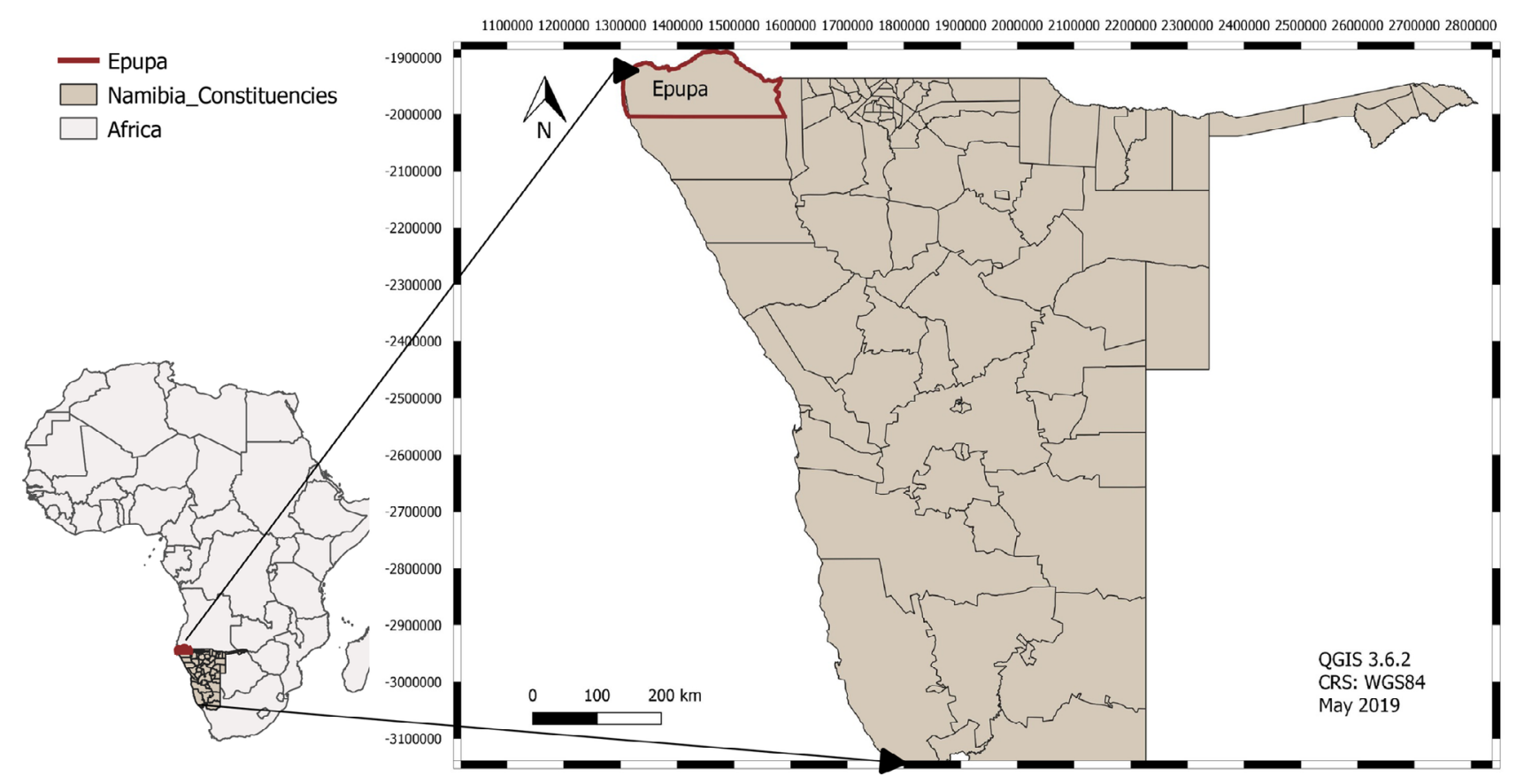

FIGURE 1 Location of the study area (red) in Kunene Region, Namibia. Left: Map of Africa, right: map of Namibia showing different constituencies, derived with QGIS, EPse32662 [Colour figure can be viewed at wileyonlinelibrary.com]

Epupa falls, south towards Opuwo and followed a track south-west going to Orutumba village. We also sampled along the gravel road to Ehomba village east of the gravel road going to Opuwo. All our points were located along the main gravel road and village tracks going to small villages, such as Orutumba. During the drives, herders pointed out different sites in each category (Figure 2). At each point, we parked the car by the road and walked for at least $200 \mathrm{~m}$ from the road to randomly select the starting point of each plot. We took GPS coordinates at each sampling point and pictures of each site. The herders selected 10 sites in each category of degradation, and we established plots of $20 \mathrm{~m} \times 20 \mathrm{~m}$ at each site. Sites were selected at least 3-6 km apart. So we had 10 sites/plots in each category of degradation. We also sampled a protected site inside Kunene River Lodge, which has been fenced off to prevent livestock access for the past 15 years. Only five plots were established and sampled in the protected area due to the small size of the protected site. In each plot, we counted all the woody plants and measured their height, as well as stem diameter (at breast height for individuals above $2 \mathrm{~m}$ and at the base of the trunk for all woody species below $2 \mathrm{~m}$ ). For each plant encountered, the herders identified it in their local language and provided information on the uses and benefits of that particular species to the local inhabitants. We sampled soil from all 35 plots. Soil samples were taken to a depth of $20 \mathrm{~cm}$ in each plot from selected points (at four corners and middle of the plot) to form a composite soil sample representing each plot. Soil samples were analysed for $\mathrm{pH}$, conductivity, organic carbon, organic matter and particle size analysis at a commercial laboratory (Analytical Laboratory Services) in Windhoek, Namibia. Standard analytical procedures were followed. All villages within the study area were geo-referenced, so for each sampling point (plot), we measured the distance to all the villages included in the study. Using visual evaluation, we assessed the grass cover, bare ground and leaf litter in each plot. This was done by using quadrats $(1 \times 1 \mathrm{~m})$ located at the centre and the four corners of each plot. Each quadrat was divided into 25 equal subsections, and cover (grass, bare and litter) was visually estimated by counting the total number of subsections covered by either grass, bare ground or leaf litter. The subsections for each type of cover were tallied (half-covered subsections were added as 0.5 , etc.) and converted to percentage cover.

\section{3 | Data analysis}

\subsection{1 | Floristic composition}

Based on the individual plants recorded in the plots, vegetation data were quantitatively analysed for basal area, relative density, relative frequency and relative dominance. The Importance Value Index (IVI) of all plant species was then determined as the sum of relative frequency, relative density, and relative dominance (Curtis, 1959). Density and standing basal area were also calculated per plot. The following formulae were used:

- Basal area, that is, cross-sectional area of a tree stem measured at breast height $\left(B A, m^{2}\right)=\mathrm{pi}^{*} \mathrm{DBH}(\mathrm{cm})^{2} / 40,000$.

- Dominance $=$ total basal area of species $\mathrm{A} /$ area sampled.

- Relative dominance $=$ dominance for species $A /$ total dominance of all species $\times 100$.

- Density = number of individuals of species $\mathrm{A} /$ area sampled.

- Relative density = (number of individuals of species $A /$ total number of individuals in the area) $\times 100$. 

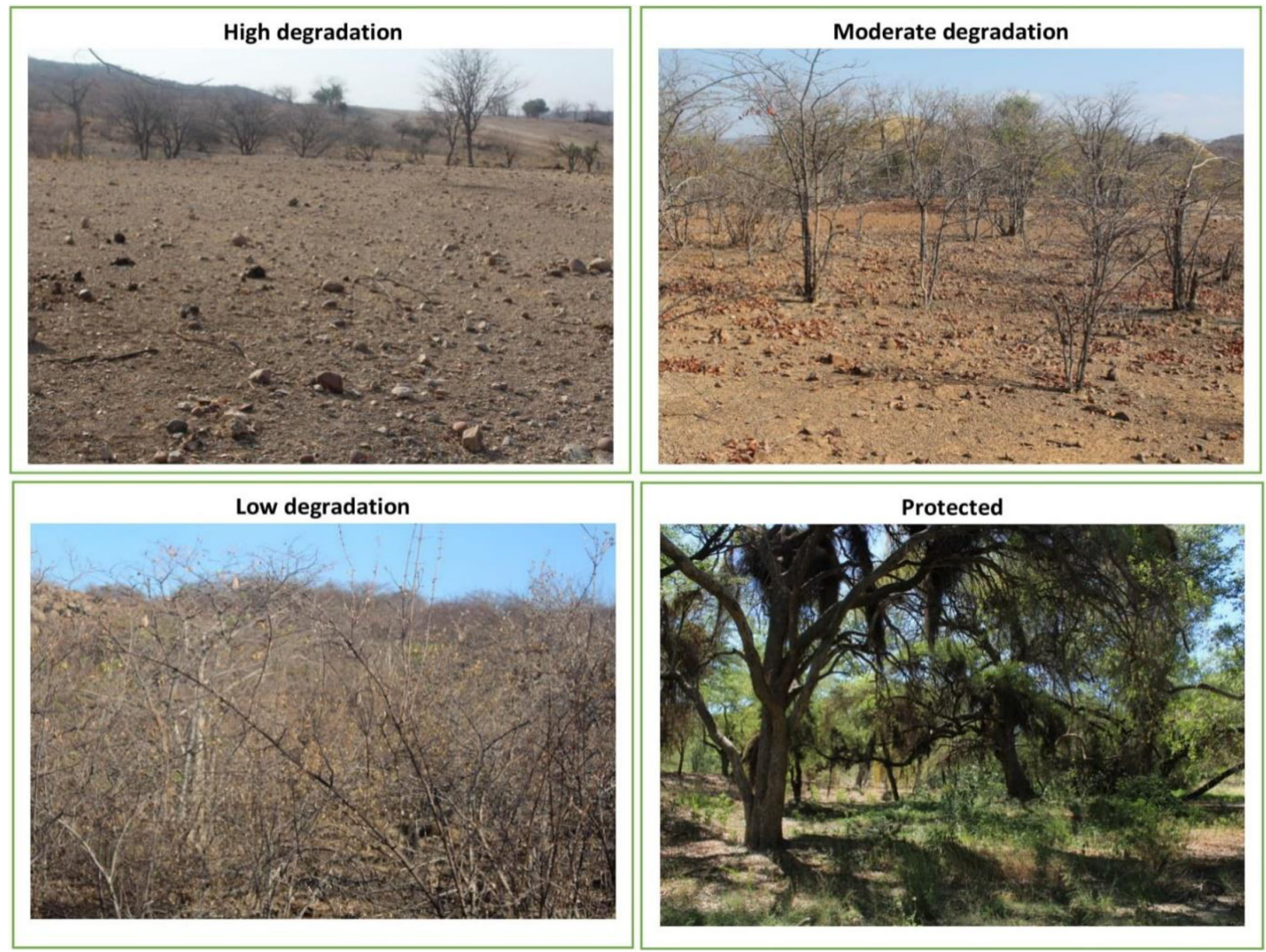

FIGURE 2 Sites representing different categories of degradation identified in the study area (Kunene Region, Namibia) [Colour figure can be viewed at wileyonlinelibrary.com]

- Frequency = number of plots in which species $\mathrm{A}$ occurs/total number of plots sampled.

- Relative frequency = frequency value for species A/total frequency values for all species.

- Importance value $=$ relative density + relative frequency + relative dominance.

For each degradation category, species diversity was calculated using the Shannon-Wiener Diversity Index (Shannon \& Wiener, 1963) and the Simpson Diversity Index (Simpson, 1949). Evenness was also determined by Pielou's Evenness Index (Pielou, 1966). Differences in the means of the diversity measures between sites, as well as density and standing basal area, were examined using generalized linear models (GLM) in Rstudio (R Core Team, 2013). All analyses were complemented with Tukey's post hoc test where appropriate. The species richness for the four degradation categories was estimated using the first-order Jackknife estimator computed in the SpadeR program (Chao, Ma, \& Hsieh, 2015). SpadeR is the R-based online version of SPADE. Like the original SPADE, it computes various biodiversity indices based on abundance data and replicated incidence data taken from one or multiple sites.

\subsection{2 | Life stages and structural composition}

Individual plants were classified into different life stages using their diameter at breast height/root collar measures (Mligo, Lyaruu, \& Ndangalasi, 2011). In order to avoid misleading interpretation of the regeneration results, a well-known perennial invasive bush-Pechuelloeschea leubnitziae-was excluded from the classification and plotted in its own category. The structural composition was analysed by comparing the distribution of different life stages. Generalised linear models (GLM) in R-studio (R Core Team, 2013) were used to determine differences in density, mean height and $\mathrm{DBH}$ of life stages among the different degradation categories.

\subsection{3 | Frequency of occurrence}

The frequency of occurrence was calculated as the proportion (\%) of the number of plots in which each woody species was recorded from the total number of plots. The SpadeR program (Chao et al., 2015) was used to separate the observed species into two groups: "rare" 
and "abundant". The former group includes species observed at most $\kappa$ (the cut-off point [default $=10$ ]) times, and the latter includes those observed at least $\kappa+1$ times. SpadeR was also used to determine the number of observed individuals for the rare group and abundant group; the number of observed species for the rare and abundant group; and to estimate the coefficient of variance for the rare group. Dominance curves for each degradation category were plotted using the Importance Value Index for each species.

\subsection{4 | Regeneration status}

Regeneration status of all the degradation categories was analysed by comparing the numbers of saplings and seedlings with the mature trees according to Dhaulkhandi, Dobhal, Bhatt, and Kumar (2008) and Tiwari, Tadele, Aramde, and Tiwari (2010). The regeneration status was regarded as good if the number of seedlings $>$ number of saplings $>$ number of poles/mature trees, fair if the number of seedlings $>$ or $\leq$ number saplings $\leq$ number poles/mature trees, and poor if the species survives only in sapling stage (number of saplings may be $\leq$ number poles/mature trees). If a species is present only in an adult form (mature tree), it is considered as not regenerating.

\subsection{5 | Community composition}

Characterisations of plant communities and species indicator analysis were performed using PC-ORD V.5 (McCune \& Mefford, 2006). The significance of all tests was determined at $\alpha \leq .05$ level. A nonparametric method called multi-response permutation procedure (MRPP) was used to test the hypothesis of no difference in species composition between the four categories (Mielke, Berry, \& Johnson, 1976). An advantage of MRPP is the fact that it does not require assumptions, such as normality and homogeneity of variances, which are rarely met with ecological community data (Mielke et al., 1976). An MRPP was carried out in PC-ORD version 5 (McCune \& Mefford, 2006) using Sorensen (Bray Curtis) as a measure of distance. We also visually represented site similarities in plant species composition using non-metric multidimensional scaling (NMDS) based on a Bray Curtis similarity matrix and displayed the first two axes. We used Pearson's correlation coefficient ( $r$ ) to examine the relationships between vegetation characteristics using IBM SPSS v. 25 (SPSS Inc, 2017).

\subsection{6 | Soil characteristics}

Generalised linear models (GLM) in R-studio (R Core Team, 2013) were used to determine the differences in soil properties between the four degradation categories. Where significant differences were found, Tukey's HSD test was applied to test for the differences between means.

\subsection{7 | Relationship between distances from the centre of villages and vegetation parameters}

We correlated the distances from the centre of villages with vegetation parameters (plant species diversity, density, standing basal area, seedling and mature tree density, height as well as density of invasive species) using Pearson correlations run in SPSS v.25 (SPSS Inc, 2017).

\subsection{8 | Percentage cover for grass, bare ground and leaf litter}

Mean grass, bare and litter cover per plot were determined for each degradation category, and GLMs were used to determine the differences in cover among the degradation categories. Where significant differences were found, we used the Tukey's HSD test to test for differences between means.

\section{$3 \mid$ RESULTS}

\section{1 | Herder perception of degradation}

Herders described degradation based on the absence or presence of woody plant species. They perceived an area that is bare or with few woody plant species as degraded. An area with a high density of woody plant species was perceived as "not degraded". Hence the absence of woody plant species was the indicator they used to measure degradation. All the herders attributed degradation to overgrazing and lack of rain. They indicated that they depended on woody rather than herbaceous plant species during prolonged drought. Most herders cited an increase in the bare ground compared to how it used to be in the past, and they seemed to know where the good, better and worst degraded areas were in their community.

\section{2 | Floristic composition and diversity}

A total of 1,662 individuals, representing 56 species from 26 families, were found in the 35 plots (Table S2). We recorded 117 individuals of 15 species in the high degradation sites, 419 individuals of 19 species in the moderate degradation sites, 881 individuals of 30 species in the low degradation sites and 245 individuals of 19 species in the protected sites. The five species with the highest Importance Value Index across all sites were Colophospermum mopane (165.7), Terminalia prunioides (59.0), Catophractes alexandri (47.5), Pechuel-loeschea leubnitziae (43.6) and Dialium engleranum (31.9). The total importance value of these five dominant species makes up $60 \%$ of the total of all the Importance Value Indices for all 56 species. Colophospermum mopane was the most abundant species in the low degradation and moderate degradation sites, while Pechuelloeschea leubnitziae and Rhus quartiniana were the most abundant species in the high degradation and protected sites, respectively. 
Species richness as estimated by first-order jackknife was lowest in the high degradation sites $(23 \pm 4.6$ species), but quite similar between the moderate degradation ( $25 \pm 3.4$ species $)$ and the protected sites ( $26 \pm 2.8$ species). The highest species richness was recorded in the low degradation sites ( $34 \pm 2.8$ species).

For the Shannon-Weiner Diversity Index, significant differences were observed between different categories of degradation $\left(F_{3}\right.$, $\left.{ }_{34}=5.247, p=.005\right)$. Average Shannon-Weiner diversity values for different categories were $0.6 \pm 0.18$ for high degradation sites, $1.2 \pm 0.13$ for moderate degradation sites, $1.3 \pm 0.12$ for low degradation sites and $1.4 \pm 0.18$ for the protected sites. However, there were no significant differences among degradation categories in Simpson and Pielou (evenness) indices of species diversity $\left(F_{3,34}=2.636\right.$, $p=.067$ and $F_{3,34}=1.308, p=.289$, respectively).

Of the 56 species recorded in the present study, only two were common in all four degradation categories, 19 species occurred only in the moderate and low degradation sites, and 34 species occurred only in one degradation category. The largest number of species occurring only in one category was recorded in the low degradation sites, followed by the protected sites, then moderate and high degradation sites (Table S3). The frequency distribution of species in the study area resulted in about $60 \%$ of species showing a low-frequency distribution (occurring only in one degradation category), and species having higher frequency classes were few or almost absent.

For the dominance curves, the three categories represented by high, moderate and low degradation sites showed a geometric distribution model, while the protected sites showed a somewhat normal distribution model (Figure S3). The geometric model showed that in the three categories, the plant communities are characterised by dominant species. SPADE analysis (Table 1) revealed that across all the degradation categories, about $70 \%$ of the species were categorised as rare. Only $30 \%$ of the total species were abundant in all the degradation categories, although the abundant species made up more than $80 \%$ of all the individuals in all the sites (Table 1).

GLM established that there was a significant difference in the mean woody species density $\left(F_{3,34}=64.124, p=.001\right)$ and standing basal area of woody species $\left(F_{3,34}=6.938, p=.010\right)$ between the four degradation categories. The highest standing basal area was recorded in the protected sites, followed by the low degradation sites and lowest in the high degradation sites (Figure 3a). The low degradation sites recorded the highest overall mean density $(2,446 \pm 241$ individuals/ha), and the high degradation sites recorded the lowest mean density (361 \pm 97 individuals/ha). The protected and moderate degradation sites had a mean density of 1,225 \pm 148 individuals/ha and 1,154 \pm 192 individuals/ha, respectively (Figure 3b).

The low degradation sites had the highest proportion and density of seedlings, saplings and poles, but not mature trees (Figures $4 a$ and S4). The high degradation sites had the highest proportion of perennial invasive bush (Pechuel-loeschea leubnitziae). Mean tree height was significantly greater $\left(F_{3,34}=5.948, p=.003\right)$ in the protected site $(11.2 \pm 4.6 \mathrm{~m})$ in comparison with the low degradation $(4.6 \pm 1.03 \mathrm{~m})$ and moderate degradation sites $(4.4 \pm 2.4 \mathrm{~m}$ ) (Figure $4 \mathrm{~b}$ ).
TABLE 1 SPADE analysis on frequency counts of rare and abundant species in different categories of degradation sampled in Kunene Region, Namibia

\begin{tabular}{|c|c|c|c|c|}
\hline Variable & $\begin{array}{l}\text { High } \\
\text { Value }\end{array}$ & Moderate & Low & Protected \\
\hline \multicolumn{5}{|l|}{ Cut-off point } \\
\hline$k$ & 10 & 10 & 10 & 10 \\
\hline \multicolumn{5}{|c|}{ Number of observed individuals for rare group } \\
\hline n_rare & 16 & 41 & 76 & 43 \\
\hline \multicolumn{5}{|c|}{ Number of observed species for rare group } \\
\hline D_rare & 13 & 13 & 21 & 13 \\
\hline \multicolumn{5}{|c|}{ Number of observed individuals for abundant group } \\
\hline n_abun & 101 & 378 & 805 & 202 \\
\hline \multicolumn{5}{|c|}{ Number of observed species for the abundant group } \\
\hline D_abun & 2 & 6 & 9 & 6 \\
\hline \multicolumn{5}{|c|}{$\%$ of rare species } \\
\hline$\%$ n_rare & 86.7 & 68.4 & 68.4 & 70.0 \\
\hline \multicolumn{5}{|c|}{$\%$ of abundant species } \\
\hline \%n_abun & 13.3 & 31.6 & 31.6 & 30.0 \\
\hline \multicolumn{5}{|c|}{$\%$ of individuals of rare species } \\
\hline \%D_rare & 13.7 & 9.8 & 8.6 & 17.6 \\
\hline \multicolumn{5}{|c|}{$\%$ of individuals of abundant species } \\
\hline \%D_abun & 86.3 & 90.2 & 91.4 & 82.4 \\
\hline
\end{tabular}

\section{3 | Community structure and similarity}

An MRPP ( $A=0.29$ and $p<.001)$ of the plant communities, identified by the total species assemblage and abundance of the plots, showed a significant difference in species composition between the sampled sites. The high degradation sites were very different from the other sites in the three categories, but the low degradation and the moderate degradation sites were quite similar (Figure 5). The two-dimensional NMDS ordination showed strong associations with several ecological gradients. Axis 1 was strongly associated with species richness, mature trees and seedlings, as well as the low degradation and protected sites. Axis 2 was strongly associated with high degradation sites and Pechuel-loeschea leubnitziae.

\section{\begin{tabular}{l|l}
3.4 & Uses of woody species
\end{tabular}}

Community members use the available plants mostly for grazing, medicine and food. They seem to have a rich knowledge of medicinal uses of plants in their area. This knowledge was passed on from generation to generation because modern medicine was not accessible to the people, and for hundreds of years, they have used traditional medicines that still work today. These medicines range from treatment of simple cases of a headache and pain to more serious sicknesses, such as sexually transmitted infections. Among the 56 sampled species, $50 \%$ are used for medicinal purposes, and more than $50 \%$ are suitable for browsing (Table 2). Herders pointed out that woody species play a significant role as a source of browse 

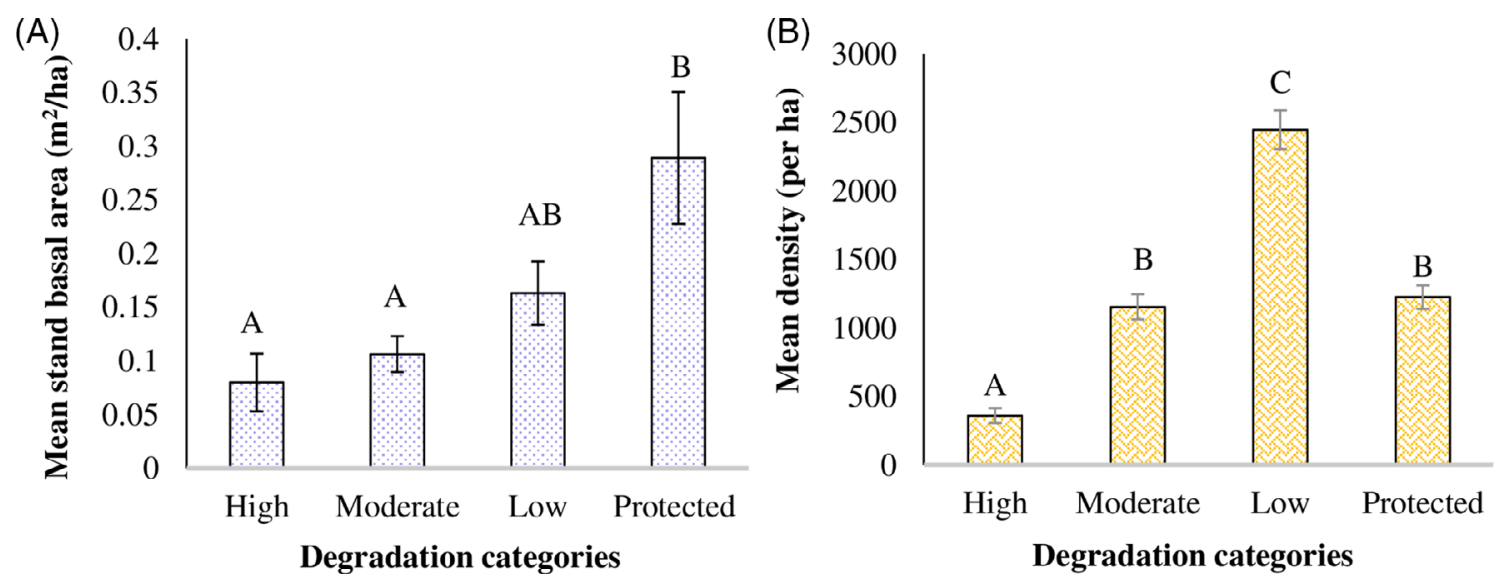

FIGURE 3 Mean ( $\pm S E$ ) standing basal area (a) and woody species density (b) compared in different categories of degradation in Epupa, Kunene Region, Namibia. Significant differences within entries are indicated with upper case letters [Colour figure can be viewed at wileyonlinelibrary.com]

(a) Seedling - Pechuel-loeschea leubnitziae $\boxminus$ Pole

Mature tree

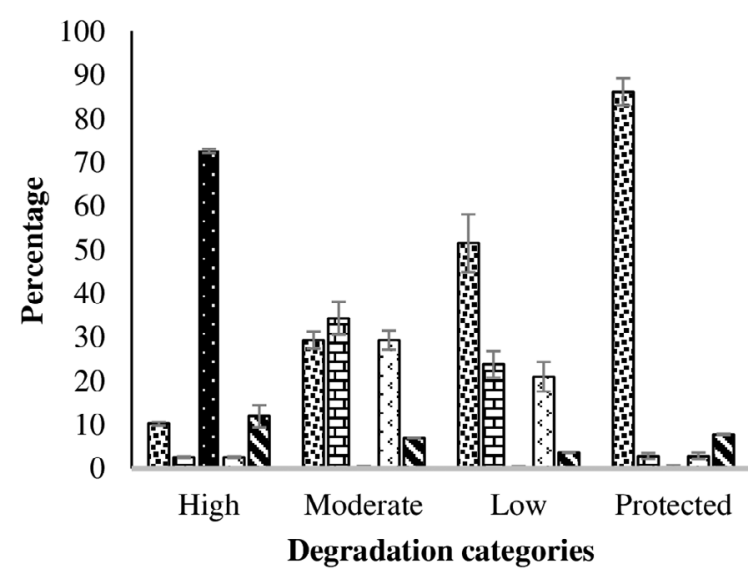

(b)

QSeedling $\square$ Sapling
$\square$ Pechuel-loeschea leubnitziae $\square$ Pole
\$ Mature tree

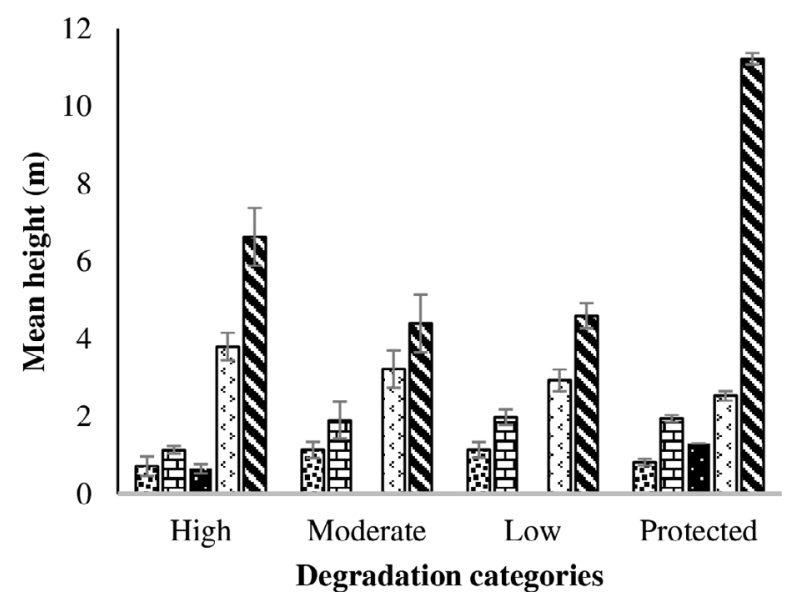

FIGURE 4 (a) Proportions and (b) Mean ( $\pm S E$ ) height of life stages compared in different degradation categories, Kunene Region, Namibia

during dry periods. Woody plant species with multiple uses falling in three or more categories include Colophospermum mopane, Catophractes alexandri, Terminalia prunioides and Grewia flava. These species were also among the five most abundant species in the community, indicating that the most available species were also the ones commonly used.

\section{5 | Soil characteristics}

We recorded significant differences in $\mathrm{pH}\left(F_{3,34}=4.247, p=.013\right)$, organic matter $\left(F_{3,34}=4.492, p=.010\right)$, organic carbon $\left(F_{3,34}=4.879\right.$, $p=.007)$, conductivity $\left(\left(F_{3,34}=4.269, p=.002\right)\right.$, sand $\left(F_{3,34}=4.880\right.$, $p=.007)$, silt $\left(F_{3,34}=4.053, p=.015\right)$ and clay $\left(F_{3,34}=6.868, p=.001\right)$, among the four degradation categories with the protected sites recording the highest organic matter, carbon and clay content (Table 3).

\subsection{Relationships between vegetation parameters and distances to the villages}

We recorded significant positive correlations between plant species diversity $(r=.550, p<.0001)$, standing basal area $(r=.892, p<.0001)$, density of mature trees $(r=.289, p<.0001)$, density of seedlings $(r=.218, p<.002)$, height of woody plants $(r=.547, p<.0001)$, woody plant abundance $(r=.152, p=.028)$ and distances from the centre of the villages. All these parameters increased with the increase in distance from the centres of the villages. We, however, recorded 


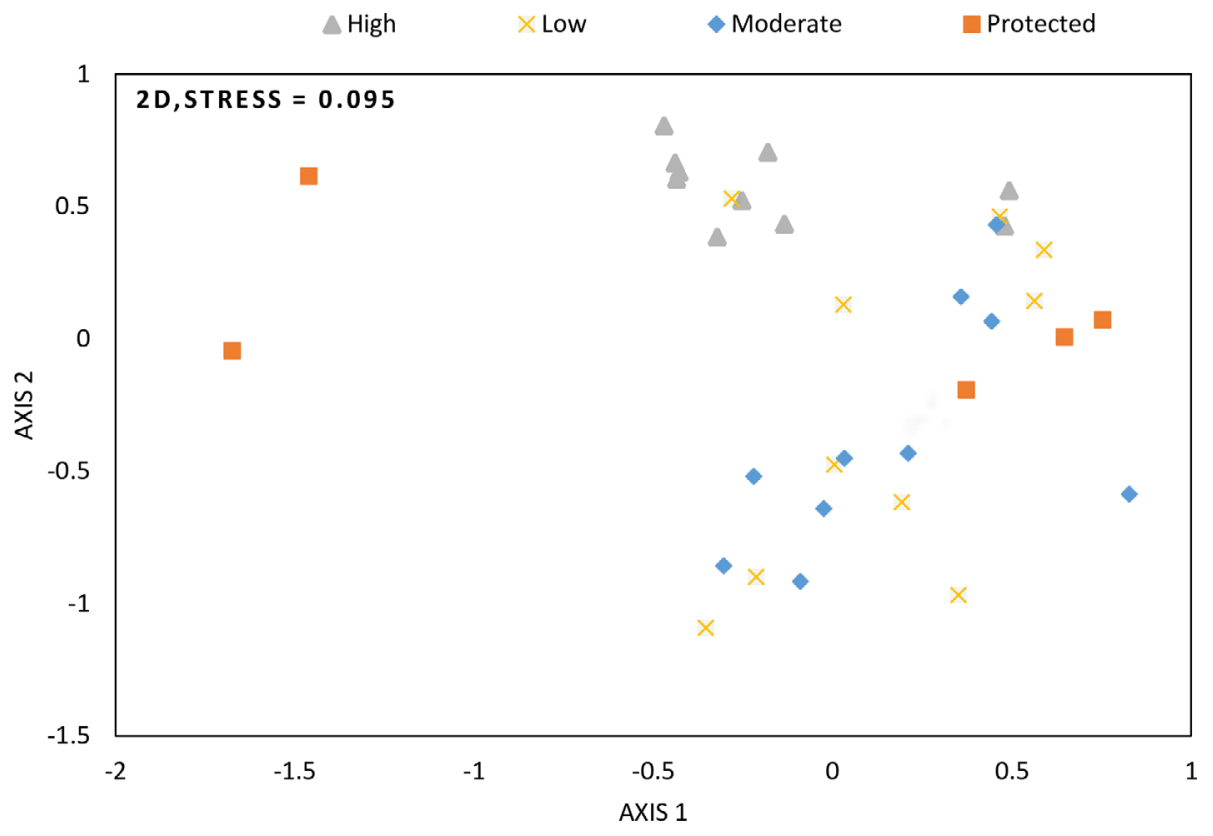

FIGURE 5 NMDS ordination based on Bray-Curtis distance measure on species composition ( $n=28$ species, three-dimensional stress $=0.095$, axis $1, r^{2}=.492$ and axis $2, r^{2}=.231 ; A=0.29$ and $p<.0$ ) [Colour figure can be viewed at wileyonlinelibrary.com] significant negative correlations between the density of an invasive shrub (Pechuel-loeschea leubnitziae) $(r=-.283, p<.0001)$, with distances from the centre of the villages. Invasive species decreased with increase in distance from the villages.

\section{7 | Percentage cover for grass, bare ground and leaf litter}

The protected sites recorded the highest grass cover, followed by moderate degradation sites. The grass cover in low and high degradation sites was very low to zero. Most high and low degradations sites had a bare ground cover. Leaf litter was highest in moderate degradation sites followed by the protected sites (Figure 6).

\section{4 | DISCUSSION}

\section{1 | Perception of degradation by community members and uses of woody species}

In this study, local land users perceived woody plant species to be more important than herbaceous plant species because woody plants provide palatable biomass in times of low resource availability, and are thus an important objective of management decisions for livestock herding in resource-scarce times (Eisold, 2010). The availability of herbaceous biomass is determined by the high variability of annual rainfall, and thus the reliability of woody species is uppermost in local perception (Eisold, 2010). Thus, in this study, degradation to the community members means an absence of or low density of woody species. Thus, the sites classified as high degradation were those that were mostly bare or with few woody species while sites with a high density of woody species were classified as low or not degraded.
Understandably, community members would perceive degradation in terms of availability of woody species because most of the benefits they get from the environment (e.g., firewood, construction materials, medicine and forage for browsing livestock) are derived from these woody species (Table 2). Pastoralists have established rich ethnobotanical knowledge based on subsistence livestock production. This knowledge comprises a cognisance of the palatability of forage species for their different livestock types and medicinal properties. Information like this is the basis for context-specific adaptation to the rapid increase of woody species in rangelands and other environmental problems (Liao et al., 2016). For example, over the years, they have shifted to keeping more goats than cattle due to their drought resistance. Medicinal plants that are used for food can also play a key role in improving human health, where diet-related diseases are widespread (Kassam et al., 2010).

\subsection{Ecological results}

\subsection{1 | Floristic diversity, richness and composition}

Diversity varied across the different categories of degradation, with the protected sites recording the highest species diversity and the high degradation sites recording the lowest. The diversity values are comparable to those from several other studies (e.g., Gobelle \& Gure, 2018; Rutherford, Powrie, \& Husted, 2014) conducted in communal or overgrazed African rangelands. This result was expectedother studies have shown that increasing frequency and intensity of disturbances leads to a decrease in plant diversity and other associated vegetation attributes (Funk \& Vitousek, 2007; Perrings, 2010). The relationships between disturbance and plant diversity, composition, structure, and regeneration have been discussed in many studies (e.g., Gautam, Manhas, \& Tripathi, 2016; Ren, Schönbach, Wan, 

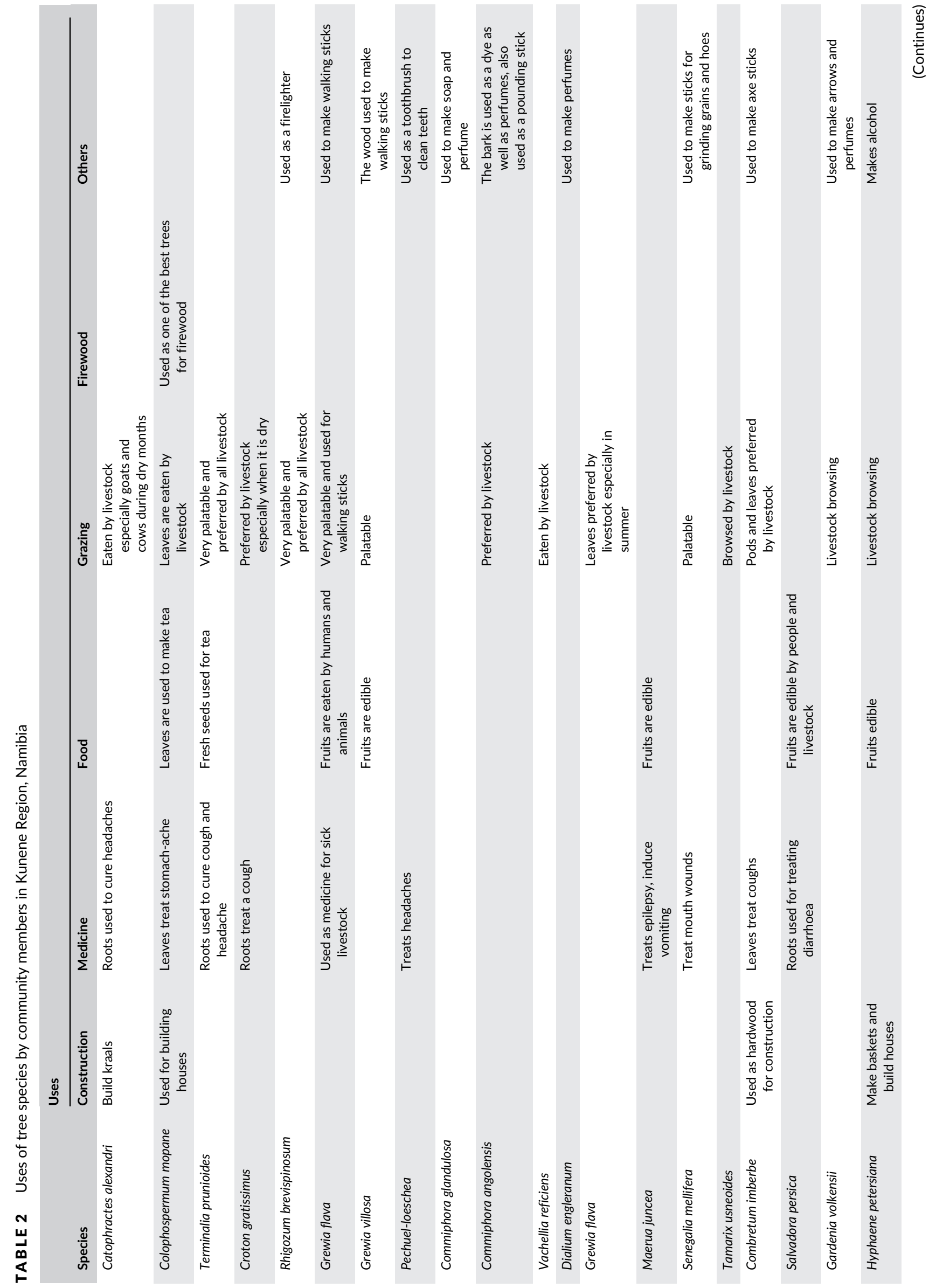

औ 


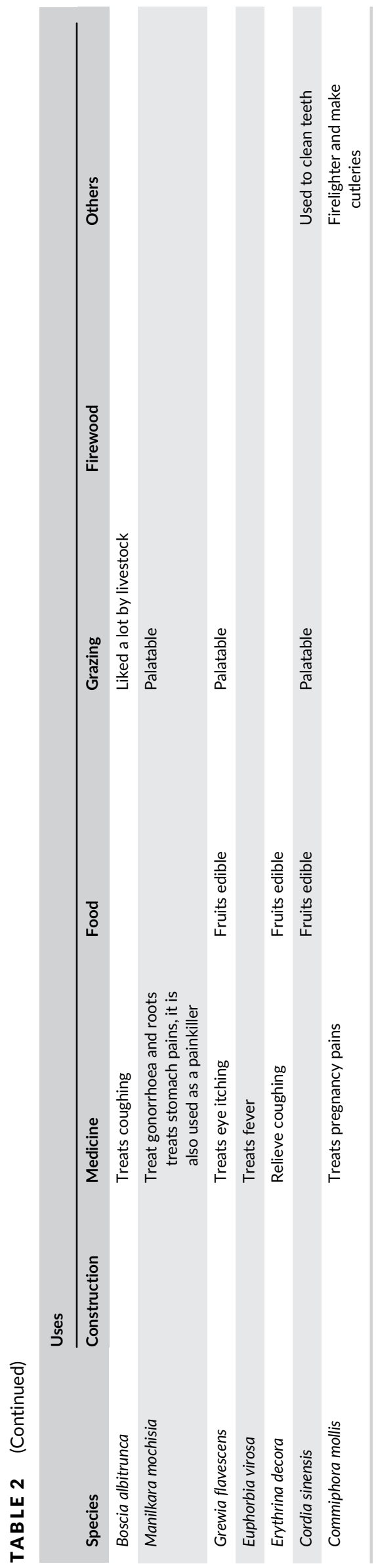

Gierus, \& Taube, 2012; Shrestha, Måren, Arneberg, Sah, \& Vetaas, 2013; Singh, Malik, \& Sharma, 2016; Symstad \& Jonas, 2011). Disturbances are perceived by many to be detrimental to plant diversity, structure, and regeneration of ecosystems because they change the environmental conditions and the ecosystem processes (Sheil \& Burslem, 2003). It is, however, important to note that disturbances can also act as an essential part of ecological systems and have critical impacts on the composition of species and diversity. The ecological impact of a disturbance is, therefore, determined by the intensity and frequency of the disturbance. Some studies (e.g., Shackleton, Griffin, Banks, Mavrandonis, \& Shackleton, 1994) found that woody stem density, basal area, biomass, height, seedling density and species richness all exhibited a significant decrease with increasing disturbance intensity.

The low plant diversity recorded in the high degradation category reflects the fact that these sites were dominated by a single speciesPechuel-loeschea leubnitziae. This species contributed nearly $90 \%$ of the total number of individuals in high degradation sites (Table S2). Pechuelloeschea leubnitziae is indigenous to Southern Africa and is a pioneer species that colonises sandy, alkaline soils, common in open woodland and grassland regions, and often occurring in disturbed areas, such as overgrazed and trampled sites (Murray-Hudson, 2009; Strohbach, 2000; Tedder, Kirkman, Morris, Trollope, \& Bonyongo, 2012). Strohbach (2000) observed that the cover of $P$. leubnitziae increased with increasing rangeland degradation. The species produces many small, wind-dispersed seeds (Murray-Hudson, 2009) and has a chamaephyte growth form and perennating buds close to the ground, making it fairly resistant to burning, and it resprouts from the base after the aboveground biomass has been burnt (Tedder et al., 2012). This makes it difficult to manage and control. The species is considered a problematic weed as it forms dense monotypic stands in grasslands and woodlands, and is associated with veld degradation and dominance of shade-tolerant, poor-quality grass species, especially in the Okavango Delta, Namibia (Tedder et al., 2012).

Although the low degradation sites recorded the highest number of species, most were rare, and the community was dominated by a few species making up $80 \%$ of all the individuals (Table 1). The same pattern was observed for the moderate degradation sites while the protected sites had a more even distribution of species abundances (Table S2). Bock, Jones, and Bock (2007) emphasised that species richness alone could be a misleading indicator of biological diversity if it is uncorrelated or negatively correlated with other key attributes of species assemblages, including evenness and the abundances of species. In the present study, there was no correlation between diversity and abundance, and although there was a strong correlation between diversity and richness, the correlation between evenness and diversity was quite weak (Table S4). Species diversity was more positively correlated with evenness than with richness among the plants. This could be attributed to the fact that assemblages of plants were numerically dominated by small subsets of common species, especially in the low degradation and high degradation sites.

Significant relationships were found between distances from the centres of the villages and woody plant species diversity, abundance, richness, height and standing basal area. While these parameters 
TABLE 3 Descriptions of soil properties in all the degradation categories. Significant differences are indicated by different lower-case letters

\begin{tabular}{|c|c|c|c|c|c|}
\hline Soil property & Degradation category & Mean & Min. & Max. & SE \\
\hline \multirow[t]{4}{*}{$\mathrm{pH}(\mathrm{H} 2 \mathrm{O})$} & High degradation & $7.70 \mathrm{~b}$ & 7.00 & 8.00 & 0.11 \\
\hline & Moderate degradation & $7.75 \mathrm{~b}$ & 6.50 & 8.40 & 0.22 \\
\hline & Low degradation & $8.18 \mathrm{a}$ & 7.50 & 8.50 & 0.15 \\
\hline & Protected & $7.36 \mathrm{c}$ & 7.60 & 8.00 & 0.10 \\
\hline \multirow[t]{4}{*}{ Conductivity (mS/m) } & High degradation & $19.3 \mathrm{~b}$ & 6.30 & 29.00 & 2.32 \\
\hline & Moderate degradation & $12.27 b$ & 4.10 & 25.00 & 2.81 \\
\hline & Low degradation & $20.25 b$ & 17.00 & 28.90 & 1.79 \\
\hline & Protected & $37.975 a$ & 24.30 & 59.40 & 7.51 \\
\hline \multirow[t]{4}{*}{ Organic matter (\% m/m OM) } & High degradation & $0.23 c$ & 0.10 & 1.00 & 0.10 \\
\hline & Moderate degradation & $0.48 \mathrm{~b}$ & 0.10 & 0.60 & 0.05 \\
\hline & Low degradation & $0.52 \mathrm{~b}$ & 0.20 & 1.20 & 0.14 \\
\hline & Protected & $1.68 \mathrm{a}$ & 1.30 & 2.10 & 0.18 \\
\hline \multirow[t]{4}{*}{ Organic carbon (\% m/m C) } & High degradation & $0.39 c$ & 0.20 & 1.70 & 0.17 \\
\hline & Moderate degradation & $0.83 b$ & 0.25 & 0.20 & 0.08 \\
\hline & Low degradation & $0.95 \mathrm{~b}$ & 0.40 & 2.10 & 0.24 \\
\hline & Protected & $2.92 \mathrm{a}$ & 2.20 & 3.60 & 0.30 \\
\hline \multirow[t]{4}{*}{ Sand \% } & High degradation & $83.25 \mathrm{a}$ & 4.42 & 76.10 & 1.47 \\
\hline & Moderate degradation & $77.55 \mathrm{~b}$ & 62.80 & 84.00 & 2.35 \\
\hline & Low degradation & $70.11 \mathrm{c}$ & 52.70 & 81.70 & 4.50 \\
\hline & Protected & $71.72 \mathrm{c}$ & 69.60 & 74.40 & 1.05 \\
\hline \multirow[t]{4}{*}{ Silt \% } & High degradation & $12.01 \mathrm{~b}$ & 2.30 & 17.70 & 1.45 \\
\hline & Moderate degradation & $16.96 \mathrm{~b}$ & 9.30 & 33.70 & 2.49 \\
\hline & Low degradation & $22.10 \mathrm{a}$ & 11.60 & 36.50 & 4.09 \\
\hline & Protected & $16.22 \mathrm{~b}$ & 14.00 & 18.90 & 1.05 \\
\hline \multirow[t]{4}{*}{ Clay \% } & High degradation & $4.73 b$ & 1.00 & 9.60 & 0.93 \\
\hline & Moderate degradation & $5.51 \mathrm{~b}$ & 3.50 & 10.10 & 0.69 \\
\hline & Low degradation & $7.78 \mathrm{~b}$ & 6.60 & 10.80 & 0.64 \\
\hline & Protected & $12.05 \mathrm{a}$ & 10.50 & 13.80 & 0.69 \\
\hline
\end{tabular}

트 Grass 를 Bare 르 Leaf litter

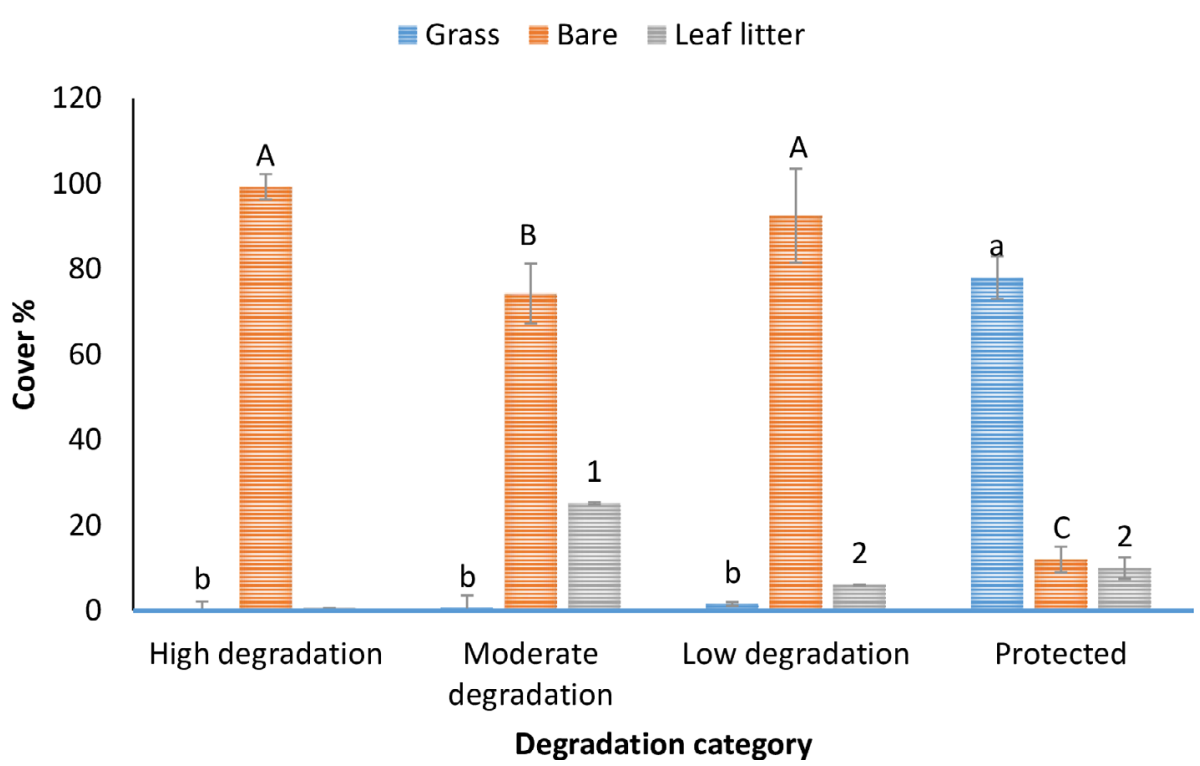

Degradation category
FIGURE 6 Mean cover (\%) and standard error (SE) for grasses, bare ground and leaf litter, estimated using a $1 \mathrm{~m}^{2}$ quadrat. General linear model analyses were used to determine differences between the degradation categories. Significant $p$ values are noted with small case letters for grass cover, big case letters for bare ground cover and numbers for leaf litter cover [Colour figure can be viewed at wileyonlinelibrary.com] 
increased with increasing distances from the centres of the villages, others, such as the density of the invasive species, decreased with increasing distances from the centre of villages. The sites closer to the villages, therefore, recorded the lowest species diversity and richness, the lowest standing basal area and mature trees, as well as poor regeneration. This points to anthropogenic disturbances in the rangeland, and the sites closest to the villages are more degraded than those further away. Activities contributing to this could be cutting down trees near their villages for building purpose, as well as harvesting medicine, and the fact that the livestock are kept in the kraals near their homestead, and, therefore, grazing on what is near them first. Grazing and trampling by livestock, as well as pressure from both livestock and people around villages, could potentially remove plant cover and create bare soil patches.

\subsection{2 $\quad$ Soil characteristics}

The protected sites recorded the highest organic matter (Table 3), and this is an indication of soil fertility and good soil health. On the contrary, high degradation and low degradation sites recorded the lowest organic matter and carbon content. Soil organic carbon is one of the key indicators for estimating soil quality and act as important carbon reservoirs (Xue \& An, 2018). Several studies have shown that grazing leads to a decrease in plant cover and soil organic carbon (He et al., 2011; Mohammed, Abule, \& Lissahanwork, 2017; Zarekia, Jafari, Arzani, Javadi, \& Jafari, 2012). This may be the case in the three categories of degradation, excluding the protected sites. The higher soil organic carbon and matter in the protected sites could be ascribed to the increased vegetation production, litter quality and nutrient cycling (Mohammed et al., 2017).

The $\mathrm{pH}$ ranged from 7.3 to 8.1 for all the degradation categories, with the high degradation sites recording the highest $\mathrm{pH}$ value (8.1) moving towards moderately alkaline soils (Table 3). According to USDA (1998), a $\mathrm{pH}$ range of 6-7 is usually most favourable for plant growth because most plant nutrients are readily available in this range. $\mathrm{A} \mathrm{pH}$ of $6.6-7.3$ is favourable for microbial activities that contribute to the availability of nitrogen, sulphur and phosphorus in soils (Abate, Ebro, \& Nigatu, 2012). Soil organic carbon in the high, moderate and low degradation sites was below 0.9 , compared with 2.8 in the protected sites (Table 3). These sites also recorded low to no grass cover in most of the plots, while the protected sites recorded a grass cover of more than $80 \%$ (Figure 6).

\subsection{3 | Density and standing structure of woody plants}

The highest woody plant density was recorded in the low degradation sites (2,446 individuals/ha) and the lowest in the high degradation sites (361 individuals/ha) (Figure 3). According to Abate et al. (2012), an increase in the woody plant density beyond a critical density limit is referred to as "bush encroached". A shrub cover of $40 \%$ and/or 2,400 woody plants/ha has been considered as a borderline between non-encroached and encroached condition (Dalle, Maass, \& Isselstein, 2006; Roques, O'Connor, \& Watkinson, 2001), with 2,500 tree equivalents/ha indicating an encroached condition (Richter, Snyman, \& Smit, 2001). In Abate and others' study, pastoralists reported that drought, overgrazing, livestock movement and absence of fire were major factors triggering bush encroachment. Abate and others claimed that there was ample evidence in the literature that bush encroachment caused a decline in rangeland condition and the respondents.

The low degradation sites in the present study are at the borderline of being classified as bush encroached. This is not surprising considering the fact that the most abundant species (Colophospermum mopane) in these sites is also classified among the nine encroaching species in Namibia (de Klerk, 2004). Smit (2005) reported that savannahs dominated by $C$. mopane in South Africa were water-limited, resulting in the suppression of herbaceous plants. Due to this suppression effect, the grazing capacity of large areas of these savannahs are known to have declined due to bush encroachment, often to such a degree that many formerly thriving livestock properties are no longer economically viable. Studies focusing on native species invasions are numerous. Examples include Grewia flava (Tews, Schurr, \& Jeltsch, 2004) in South Africa, which was the second most abundant species in the low degradation sites in this study, Vachellia species (Ward, Hoffman, \& Collocott, 2014), Dichrostachys cinerea and Grewia bicolor in Swaziland (Roques et al., 2001). Encroachment has, in some cases, resulted in the loss of available grazing land (Moleele, Ringrose, Matheson, \& Vanderpost, 2002) reduced species richness (Price \& Morgan, 2008) and loss of biodiversity (Gobelle \& Gure, 2018). Grasses generally have shallow roots and higher relative growth rates, while shrubs have deep roots that can reach the water table (Gaitán et al., (2014)), making shrubs more drought-tolerant than grasses.

A substantial body of thought suffusing the literature suggests that bush encroachment is an ecological expression of degradation or desertification (e.g., Báez \& Collins, 2008; Havstad, Fredrickson, \& Huenneke, 2006; MEA, 2005; Schlesinger et al., 1990). It is, however, important to note that the ecological impacts of bush encroachment processes are diverse, and often ambiguous, ranging from negative through neutral to positive depending on the particular ecosystem and function (Wagner, Hane, Joubert, \& Fischer, 2016). While some scholars classify bush encroachment as a form of degradation, some have argued that it is not necessarily degradation because, in some cases, it can increase desirable ecosystem attributes. Eldridge et al. (2013) argued that a single interpretation of bush encroachment as a form of degradation is not possible and that perspectives on the adverse effects of bush encroachment have been strongly influenced by the prevalence of pastoralism involving grass-feeding livestock. If both human and natural systems are considered, there are multiple components of the encroachment outcome; utilitarian, functional and structural.

\subsection{4 | Regeneration}

Singh et al. (2016) established that the health of plant communities depended on the potential regenerative status of species in space and 
time. We found that the high degradation sites showed poor regeneration, having fewer seedlings than mature trees (Figure 4). The regeneration status for the protected sites and the low degradation sites was "good" because the density of seedlings was higher than the density of saplings and mature trees, and "fair" for the moderate degradation sites, because the density of seedlings was lower than that of saplings and poles. Kikoti, Mligo, and Kilemo (2015) obtained similar results in Tanzania, where the number of seedlings was significantly higher in the least and ungrazed areas than heavily and moderately grazed areas. The ratio of various age groups of plants in a population determines the reproductive status of the population and indicates its future course (Malik \& Bhatt, 2016). Ballabha, Tiwari, and Tiwari (2013) and Malik and Bhatt (2016) pointed out that some anthropogenic disturbances, such as forest fires, overgrazing and lopping, affect both plant diversity and their regeneration. More often, the plant regeneration process is adversely affected by the uncontrolled grazing by domestic livestock, which removes young seedlings and saplings, causing soil loss due to trampling, and this is likely to be the case for this study.

\subsection{5 | Matching the perception of degradation with ecological results}

Our results show that the herders' perception of degradation for high and moderate degradation matches the ecological results. For example, the ecological results show that diversity, richness, regeneration and density of woody plant species increased in order along the degradation gradient from high to low levels of degradation. As classified by herders, the high degradation sites recorded the lowest species richness, the poorest regeneration, low organic carbon and matter, as well as the lowest density of woody plant species, followed by moderate degradation. On the other hand, the ecological results indicated that the sites perceived as being in the low degradation category are, in fact, at the borderline of another form of degradation-bush encroachment (having a density of more than 2,400 plants/ha). The ecological results also recorded the second-lowest organic matter and carbon in these sites, indicating poor soil fertility. Soil organic carbon threshold for sustaining soil quality is widely suggested to be about $2 \%$, below which deterioration may occur (Patrick et al., 2013). Therefore, the area also classified as least degraded or not degraded, by herders, could be interpreted as being degraded according to the results. However, bush encroachment is the type of degradation that community members do not currently recognise because woody species provide important benefits, especially in times of scarcity. According to Katjiua and Ward (2012), while bush encroachment may reduce range productivity on some Namibia rangelands, it may also provide valuable forage for livestock production on other rangelands. In a case like this, the pastoralists will perceive bush encroachment as a positive outcome of vegetation change. Woody plant species also provide shelter for livestock, building materials, medicine and fuelwood. Thus, current levels of bush encroachment in this study were regarded as beneficial to the communities.
It may be that the herders are not looking at the bigger picture of the whole ecosystem but only from the perspective of what helps them. Here, the indicator of degradation is the absence of woody species to community members. According to Ibrahim (2017), the pastoralist's view of land degradation is not a complex relationship between landscape and the vegetation, but rather in the context of the availability of pasture. To them, land degradation takes place when the landscape can no longer provide enough for their livestock. Pastoralists farming with grass-eating livestock will probably see bush encroachment as a problem due to a reduction in grass availability, while pastoralists farming with mainly browsers, such as goats, may not see bush encroachment as a problem. This may be the case in this study because most of the community members farm mainly with goats. Other studies looking at the perception of degradation by farmers have shown different opinions, with some recognising bush encroachment (e.g., Abate et al., 2012; Angassa \& Oba, 2008) and others stating the benefits of bush encroachment (e.g., Wigley, Bond, \& Hoffman, 2009). So where to from here? If the future of the rangeland will be affected by increasing shrub encroachment, how can this be rectified when farmers do not see it as a problem? Moreover, where does one draw a line in terms of what degradation truly means? Hobbs (2016) suggested that the perception of degradation is subjective; people can have fairly different perspectives about the same landscape. A certain forest may seem impoverished to a wildlife enthusiast, but a forester may see it as a productive forest regenerating after logging. Likewise, a forester may see a degraded forest while a shifting cultivator sees a piece of prime agricultural land. Unescapably, 'degradation' is in the eye of the beholder.

\section{5 | CONCLUSIONS}

This study sought to address the current status of woody vegetation in different perceived levels of degradation in the selected rangeland. The results revealed that the study area currently had patches differing in vegetation attributes and regeneration potentials. Species diversity, seedling density, basal area and regeneration of woody plants increased sequentially from high degradation to low degradation. The degradation categories occur in the same rangeland under the same climate, sharing similar environmental conditions, and yet differing in vegetation attributes. This points to anthropogenic disturbances causing changes in the vegetation structure and composition in this rangeland. The area classified as low degradation by community members shows signs of another type of degradation-bush encroachment, suggesting that bush encroachment is not perceived as degradation. The findings from the ecological sampling highlight the present and future threats the study area is facing, including bush encroachment, bare patches and an increase of unpalatable annual herbs/shrubs. The high degradation sites are dominated by an undesirable and unpalatable herb and show poor regeneration, very low species diversity and richness, and this is cause for concern. It is likely that, in the absence of intervention, even the low degradation sites will eventually become heavily degraded in the future. Without some form of intervention to 
improve the ecological situation, it is hard to imagine the future of the people living in the area, 10 and 20 years from now. There is an urgent need to find effective interventions that can improve rangeland condition and subsequently help sustain the livelihood of many living there. Sharing knowledge between local people and researchers may be helpful because both parties can learn from each other. Dealing with land degradation will require a behaviour change that may be promoted through increased knowledge. Farmers can no longer afford to just focus on food production, without considering the ecosystem processes that ensure long-term production and provide other essential resources required, such as for their well-being (Ingram, DeClerck, \& del Rio, 2012). The way forward will require synergistic effort from farmers, researchers, educators, among others.

\section{ACKNOWLEDGMENTS}

This work was supported by Russel E. Train Fellowship WWF grant number SZ43. The authors acknowledge Mr Kuooko Daniel from Epupa Constituency Office, Kunene Region, Namibia, for helping us get permissions to conduct research in the area and mobilising community members' participation, and Rebecca Campbell (UWA) for logistical support. We also thank the University of Namibia for granting the senior author study leave to be able to carry out this study. Lastly, special gratitude goes to the local communities, who willingly collaborated and participated in the project. We gratefully thank all the landowners who allowed us unlimited access to their properties, without which this study would not have been possible. Special thanks to Peter Morgan for granting permission to sample in the lodge and giving us climate data for the area.

\section{ORCID}

Emilia N. Inman (D) https://orcid.org/0000-0002-1350-9768

\section{REFERENCES}

Abate, T., Ebro, A., \& Nigatu, L. (2012). Evaluation of rangeland in arid and semi-arid grazing land of south East Ethiopia. International Journal of Agricultural Sciences, 2(7), 221-234.

Abdi, O. A., Glover, E. K., \& Luukkanen, O. (2013). Causes and impacts of land degradation and desertification: Case study of The Sudan. International Journal of Agriculture and Forestry, 3(2), 40-51. https://doi.org/ 10.5923/j.ijaf.20130302.03

Angassa, A., \& Oba, G. (2008). Herder perceptions on impacts of range enclosures, crop farming, fire ban and bush encroachment on the rangelands of Borana, Southern Ethiopia. Human Ecology, 36, 201-2015. https://doi.org/10.1007/sl

Albuquerque, U. P., Gonçalves, P. H. S., Ferreira Júnior, W. S., Chaves, L. S., Oliveira, R. C. da S., Silva, T. L. L. da, Santos, G. C. dos, \& Araújo, E. de L. (2018). Humans as niche constructors: Revisiting the concept of chronic anthropogenic disturbances in ecology. Perspectives in Ecology and Conservation, 16, 1-11. https://doi.org/10.1016/j.pecon.2017.08.006

Báez, S., \& Collins, S. L. (2008). Shrub invasion decreases diversity and alters community stability in northern Chihuahuan desert plant communities. PLoS One, 3(6), e2332. https://doi.org/10.1371/journal. pone.0002332

Ballabha, R., Tiwari, J. T., \& Tiwari, P. (2013). Regeneration of tree species in the sub-tropical forest of Alaknanda Valley, Garhwal Himalaya, India. Forest Science and Practice, 15, 89-97
Bedunah, D. J., \& Angere, J. P. (2012). Rangeland degradation, poverty, and conflict: How can rangeland scientists contribute to effective responses and solutions? Rangeland Ecology \& Management, 65, 6-612. https://doi.org/10.2111/REM-D-11

Behmanesh, B., Barani, H., Abedi Sarvestani, A., Reza Shahraki, M., \& Sharafatmandrad, M. (2016). Rangeland degradation assessment: A new strategy based on the ecological knowledge of indigenous pastoralists. Solid Earth, 7(2), 611-619. https://doi.org/10.5194/se-7-6112016

Bhowmik, A., Kukal, S. S., Saha, D., Sharma, H., Kalia, A., \& Sharma, S. (2019). Potential indicators of soil health degradation in different land use-based ecosystems in the Shiwaliks of northwestern India. Sustainability, 11(14), 3908. https://doi.org/10.3390/su11143908

Bock, C. E., Jones, Z. f., \& Bock, J. h. (2007). Relationships between species richness, evenness, and abundance in a southwestern savanna. Ecology, 88(5), 1322-1327.

Briske, D. D., Fuhlendorf, S. D., \& Smeins, F. E. (2005). State-and-transition models, thresholds, and rangeland health: A synthesis of ecological concepts and perspectives. Rangeland Ecology and Management, 58(1), 1-10. https://doi.org/10.2111/1551-5028(2005)58<1:SMTARH>2.0. $\mathrm{CO} ; 2$

Caspari, T., van-Lynden, G., \& Bai, Z. (2015). Land Degradation Neutrality: An Evaluation of Methods (K. Ehlers (ed.)). Umweltbundesamt. https://www.umweltbundesamt.de/sites/default/files/medien/378/ publikationen/texte_62_2015_land_degradation_neutrality_0.pdf

Chao, A., Ma, K. H., \& Hsieh, T. C. (2015). T1 - User's Guide for Online Program SpadeR (Species-richness Prediction And Diversity Estimation in R). http://doi.org/10.13140/RG.2.2.20744.62722

Cheikhyoussef, A., Mapaure, I., \& Shapi, M. (2011). The use of some indigenous plants for medicinal and other purposes by local communities in Namibia with emphasis on Oshikoto region: A review. Research Journal of Medicinal Plant, 5(4), 406-419.

Cummings, A. R., \& Read, J. M. (2016). Drawing on traditional knowledge to identify and describe ecosystem services associated with northern Amazon's multiple-use plants. International Journal of Biodiversity Science, Ecosystem Services and Management, 12(1-2), 39-56. https://doi. org/10.1080/21513732.2015.1136841

Curtis, J. T. (1959). The vegetation of Wisconsin-An ordination of plant community, Madison, USA: University Wisconsin Press.

Dabasso, B. H., Oba, G., \& Roba, H. G. (2012). Livestock-based knowledge of rangeland quality assessment and monitoring at landscape level among Borana herders of northern Kenya. Pastoralism, 2(2), 1-13. https://doi.org/10.1186/2041-7136-2-2

Dalle, G., Maass, B. L., \& Isselstein, J. (2006). Encroachment of woody plants and its impact on pastoral livestock production in the Borana lowlands, southern Oromia, Ethiopia. African Journal of Ecology, 44(2), 237-246. https://doi.org/10.1111/j.1365-2028.2006.00638.x

Darkoh, M. B. K. (1993). Desertification: The scourge of Africa. Tiempo, 8 , 320-331.

David, L., \& Don, G. (2003). Rehabilitation and Restoration of Degraded Forests. IUCN, Gland, Switzerland and Cambridge, UK.

de Klerk, J. (2004). Bush Encroachment in Namibia: Report on Phase 1 of the Bush Encroachment Research, Monitoring, and Management Project. John Meinert Printing (Pty) Ltd. https://www.n-big.org/portfolio/ single-item/send/5-reports/14-bush-encroachment-in-namibia-deklerk-2004.html

Dhaulkhandi, M., Dobhal, A., Bhatt, S., \& Kumar, M. (2008). Community structure and regeneration potential of natural Forest site in Gangotri, India. Journal of Basic and Applied Sciences, 4(1), 49-52.

Eisold, J. (2010). Rangeland use in Northwestern Namibia: An integrated analysis of vegetation dynamics, decision-making processes and environment perception [der Universität zu Köln]. https://pdfs.semanticscholar.org/ 8f8e/4c949f71a77567b8d9f40ad6289474319ad2.pdf?_ga=2.24691507 3.448413984.1592469405-546878738.1592469405 
Eldridge, D. J., Bowker, M. A., Maestre, F. T., Roger, E., Reynolds, J. F., \& Whitford, W. G. (2013). Impacts of shrub encroachment on ecosystem structure and functioning: Towards a global synthesis. Europe PubMed, 14(7), 709-722. https://doi.org/10.1111/j.1461-0248.2011.01630.x. Impacts

Food and Agriculture Organization. (2016). Assessment of impacts and recovery needs of communities affected by El Niño-induced drought in Kunene, Erongo and Omusati regions of Namibia, Rome: Food and Agriculture Organization of the United Nations. http://www.fao.org/3/ai6604e.pdf.

Funk, J. L., \& Vitousek, P. M. (2007). Resource-use efficiency and plant invasion in low-resource systems. Nature, 446(7139), 1079-1081. https://doi.org/10.1038/nature05719

Gaitán, J. J., Oliva, G. E., Bran, D. E., Maestre, F. T., Aguiar, M. R., Jobbágy, E. G., ... Massara, V. (2014). Vegetation structure is as important as climate for explaining ecosystem function across Patagonian rangelands. Journal of Ecology, 102(6), 1419-1428. https://doi.org/10. 1111/1365-2745.12273

Gautam, M. K., Manhas, R. K., \& Tripathi, A. K. (2016). Patterns of diversity and regeneration in unmanaged moist deciduous forests in response to disturbance in Shiwalik Himalayas, India. Journal of Asia-Pacific Biodiversity, 9(2), 144-151. https://doi.org/10.1016/j.japb.2016.01.004

Gobelle, S. K., \& Gure, A. (2018). Effects of bush encroachment on plant composition, diversity and carbon stock in Borana rangelands. International Journal of Biodiversity and Conservation, 10, 230-245. https:// doi.org/10.5897/IJBC2017.1143

Gomiero, T. (2016). Soil degradation, land scarcity and food security: Reviewing a complex challenge. Sustainability (Switzerland), 8(3), 1-41. https://doi.org/10.3390/su8030281

Havstad, K., Fredrickson, E., \& Huenneke, L. (2006). Grazing livestock management in an arid ecosystem. In K. Havstad, L. Huenneke, \& W. Schlesinger (Eds.), Structure and function of a Chihuahuan Desert ecosystem: The Jornada Basin long-term ecological research site (pp. 278-304). New York, USA: Oxford University Press.

He, N. P., Zhang, Y. H., Yu, Q., Chen, Q. S., Pan, Q. M., Zhang, G. M., \& Han, X. G. (2011). Grazing intensity impacts soil carbon and nitrogen storage of continental steppe. Ecosphere, 2(1), 1-10. https://doi.org/ 10.1890/ES10-00017.1

Hobbs, R. J. (2016). Degraded or just different ? Perceptions and value judgements in restoration decisions. Restoration Ecology, 24(2), 153-158. https://doi.org/10.1111/rec.12336

Hodgson, R. E. (1975). The sub-Sahara African rangeland resource. In ILCA (Ed.), Evaluation and mapping of tropical African rangelands. Addis Ababa, Ethiopia: International Livestock Centre for Africa.

Ibrahim, Y. Z. (2017). Vegetation and land cover change in the context of land degradation in sub-Saharan West Africa. University of Leicester. https:// Ira.le.ac.uk/bitstream/2381/39744/1/2017IBRAHIMYZPhD.pdf

Imeson, A. (2012). Desertification, land degradation and sustainability, West Sussex, United Kingdom: John Wiley \& Sons.

Ingram, J. C., DeClerck, F., \& del Rio, C. R. (2012). Integrating ecology and poverty reduction: Ecological dimensions. Sprinkerlink. New York, USA. https://doi.org/10.1007/978-1-4419-0633-5.

Integrated Environmental Consultants Namibia. (2011). Let's act to adapt, dealing with climate change, a community information toolkit on adaptation (Issue September), Windhoek, Namibia: John Meinert Printing (Pty) Ltd.

Jamsranjav, C., Fernández-Giménez, M. E., Reid, R. S., \& Adya, B. (2019). Opportunities to integrate herders' indicators into formal rangeland monitoring: An example from Mongolia. Ecological Applications, 29(5), 1-20. https://doi.org/10.1002/eap.1899

Kacholi, D. S. (2014). Analysis of structure and diversity of the Kilengwe Forest in the Morogoro region, Tanzania. International Journal of Biodiversity, 2014(ii), 516840. https://doi.org/10.1155/2014/516840

Kassam, K. A., Karamkhudoeva, M., Ruelle, M., \& Baumflek, M. (2010). Medicinal plant use and health sovereignty: Findings from the Tajik and Afghan Pamirs. Human Ecology, 38(6), 817-829. https://doi.org/ 10.1007/s10745-010-9356-9

Katjiua, M., \& Ward, D. (2012). Soil and vegetation changes under livestock production in the northern Kalahari, Namibia. Dinteria, 32, 52-69.

Kessler, A., \& Stroosnijder, L. (2010). Debating land degradation: Strategy development for Bolivian Mountain valleys. Land Degradation and Development, 21(5), 480-483. https://doi.org/10.1002/ldr.986

Kgosikoma, O., Mojeremane, W., \& Harvie, B. A. (2012). Pastoralists' perception and ecological knowledge on savanna ecosystem dynamics in semi-arid Botswana. Ecology and Society, 17(4), 1-27. https://doi.org/ 10.5751/ES-05247-170427

Khwarae, G. (2006). Community perceptions of rangeland degradation and Management Systems in Loologane and Shadishadi. Norwegian University of Life Sciences.

Kikoti, I. A., Mligo, C., \& Kilemo, D. B. (2015). The impact of grazing on plant natural regeneration in northern slopes of Mount Kilimanjaro, Tanzania. Open Journal of Ecology, 05(06), 266-273. https://doi.org/ 10.4236/oje.2015.56021

Kunene Regional Council. (2015). Kunene regional development profile 2015: The ultimate frontier.

Liao, C., Ruelle, M. L., \& Kassam, K. A. S. (2016). Indigenous ecological knowledge as the basis for adaptive environmental management: Evidence from pastoralist communities in the horn of Africa. Journal of Environmental Management, 182, 70-79. https://doi.org/10.1016/j. jenvman.2016.07.032

Lukomska, N., Quaas, M. F., \& Baumgärtner, S. (2014). Bush encroachment control and risk management in semi-arid rangelands. Journal of Environmental Management, 145, 24-34. https://doi.org/10.1016/j. jenvman.2014.06.005

Mahyou, H., Tychon, B., Balaghi, R., Louhaichi, M., \& Mimouni, J. (2016). A knowledge-based approach for mapping land degradation in the arid rangelands of North Africa. Land Degradation \& Development, 27(6), 1574-1585. https://doi.org/10.1002/ldr.2470

Malik, Z. A., \& Bhatt, A. B. (2016). Regeneration status of tree species and survival of their seedlings in Kedarnath wildlife sanctuary and its adjoining areas in Western Himalaya, India. Tropical Ecology, 57(4), 677-690.

McCune, B., \& Mefford, M. J. (2006). PC-ORD. Multivariate Analysis of Ecological Data. Version 5. MjM Software, Gleneden Beach, Oregon, U.S.A.

Mendelsohn, J. (2003). Atlas of Namibia: A portrait of the land and its people, Cape Town, South Africa: David Philips Publishers.

Mendelsohn, J., Jarvis, A., Roberts, C., \& Robertson, T. (2002). Atlas of Namibia: A portrait of the land and its people, Cape Town, South Africa: David Philip Publishers.

Mielke, P. W., Berry, K., \& Johnson, E. S. (1976). Multi-response permutation procedures for a priori classifications. Communication in StatisticsTheory and Methods, 5(14), 1409-1424.

Millennium Ecosystem Assessment (MEA) (2005). Ecosystem services provided by birds. In Ecosystems and human well-being (Vol. 5), Washington, DC: Island Press. https://doi.org/10.1196/annals.1439.003

Mishra, A. K., Behera, S. K., Singh, K., Mishra, R. M., Chaudhary, L. B., \& Singh, B. (2013). Effect of abiotic factors on understory community structures in moist deciduous forests of northern India. Forest Science and Practice, 15(4), 261-273. https://doi.org/10.1007/s11632-0130415-3

Mligo, C., Lyaruu, H. V. M., \& Ndangalasi, H. J. (2011). The effect of anthropogenic disturbances on population structure and regeneration of Scorodophloeus fischeri and Manilkara sulcata in coastal forests of Tanzania. Southern Forests, 73(1), 33-40. https://doi.org/10.2989/ 20702620.2011.574830

Mohammed, M., Abule, E., \& Lissahanwork, N. (2017). Soil organic carbon and total nitrogen stock response to traditional enclosure management in eastern Ethiopia. Journal of Soil Science and Environmental Management, 8(2), 37-43. https://doi.org/10.5897/jssem2015.0545 
Moleele, N. M., Ringrose, S., Matheson, W., \& Vanderpost, C. (2002). More woody plants? The status of bush encroachment in Botswana's grazing areas. Journal of Environmental Management, 64(1), 3-11. https://doi. org/10.1006/jema.2001.0486

Murray-Hudson, M. (2009). Floodplain vegetation response to flood regime in the seasonal Okavango Delta, Botswana ( $\mathrm{PhD}$ thesis). The University of Florida. https://ufdc.ufl.edu/UFE0024728/00001

National Planning Commission (NPC). (2015). Namibia poverty mapping.

Niamir-Fuller, M. (1999). Managing mobility in African rangelands: The legitimization of transhumance, Rugby, United Kingdom: Intermediate Technology Publications.

Otieno, N. E., \& Analo, C. (2012). Local indigenous knowledge about medicinal plants in and around Kakamega forest in western Kenya. F1000Research, 1(40), 1. https://doi.org/10.12688/f1000research.140.v1

Papanastasis, V. P. (2009). Restoration of degraded grazing lands through grazing management: Can it work? Restoration Ecology, 17(4), 441-445. https://doi.org/10.1111/j.1526-100X.2009.00567.x

Patrick, M., Tenywa, J. S., Ebanyat, P., Tenywa, M. M., Mubiru, D. N., Basamba, T. A., \& Leip, A. (2013). Soil organic carbon thresholds and nitrogen Management in Tropical Agroecosystems: Concepts and prospects. Journal of Sustainable Development, 6(12), 31-43. https:// doi.org/10.5539/jsd.v6n12p31

Perrings, C. (2010). Biodiversity, Ecosystem Services, and Climate Change - The Economic Problem. In Environment Department Paper (Issue 120, p. 45). The International Bank for Reconstruction and Development. https://doi.org/10.1016/j.ecocom.2010.04.007

Pielou, E. C. (1966). The measurement of diversity in different types of biological collections. Journal of Theoretical Biology, 13(C), 131-144. https://doi.org/10.1016/0022-5193(66)90013-0

Plesnik, J., Hosek, M., \& Condé, S. (2011). A concept of a degraded ecosystem in theory and practice - a review (A/2011). European Environmental Agency. https://pdfs.semanticscholar.org/dd5d/0f133494b4271d9de37f9d2ac5666 259835f.pdf

Price, J. N., \& Morgan, J. W. (2008). Woody plant encroachment reduces species richness of herb-rich woodlands in southern Australia. Austral Ecology, 33(3), 278-289. https://doi.org/10.1111/j.1442-9993.2007. 01815.x

R Core Team. (2013). R: A language and environment for statistical computing, Boston, United Kingdom: R Foundation for Statistical Computing.

Rakotoarivelo, N. H., Rakotoarivony, F., Ramarosandratana, A. V., Jeannoda, V. H., Kuhlman, A. R., Randrianasolo, A., \& Bussmann, R. W. (2015). Medicinal plants used to treat the most frequent diseases encountered in Ambalabe rural community, eastern Madagascar. Journal of Ethnobiology and Ethnomedicine, 11(68), 1-16. https://doi.org/ 10.1186/s13002-015-0050-2

Reed, M. S., Stringer, L. C., Dougill, A. J., Perkins, J. S., Atlhopheng, J. R., Mulale, K., \& Favretto, N. (2015). Reorienting land degradation towards sustainable land management: Linking sustainable livelihoods with ecosystem services in rangeland systems. Journal of Environmental Management, 151, 472-485. https://doi.org/10.1016/j.jenvman.2014. 11.010

Ren, H., Schönbach, P., Wan, H., Gierus, M., \& Taube, F. (2012). Effects of grazing intensity and environmental factors on species composition and diversity in typical steppe of Inner Mongolia, China. PLoS One, 7 (12), e52180. https://doi.org/10.1371/journal.pone.0052180

Richter, C. G. F., Snyman, H. A., \& Smit, G. N. (2001). The influence of tree density on the grass layer of three semi-arid savanna types of southern Africa. African Journal of Range and Forage Science, 18(2-3), 103-109. https://doi.org/10.2989/10220110109485762

Roques, K. G., O'Connor, T. G., \& Watkinson, A. R. (2001). Dynamics of shrub encroachment in an African savanna: Relative influences of fire, herbivory, rainfall and density dependence. Journal of Applied Ecology, 38(2), 268-280. https://doi.org/10.1046/j.1365-2664.2001.00567.x
Rutherford, M. C., Powrie, L. W., \& Husted, L. B. (2014). Herbivore-driven land degradation: Consequences for plant diversity and soil in arid subtropical thicket in south-eastern Africa. Land Degradation and Development, 25(6), 541-553. https://doi.org/10.1002/ldr.2181

Schlesinger, W. H., Reynolds, J. F., Cunningham, G. L., Laura, F., Jarrell, W. M., Virginia, R. A., ... Jarrell, W. M. (1990). Articles biological feedbacks in global desertification conceptual models for desertification. Science, New Series, 247(4946), 1043-1048.

Schneiderat, U. (2011). Communal rangelands in northern and central Namibia: the grazing and browsing resources and their users [der Justus-Liebig-Universität Gießen Eingereicht]. http://geb.uni-giessen. de/geb/volltexte/2012/8595/

Seely, M. K., \& Jacobson, K. M. (1994). Desertification and Namibia: A perspective. Journal of African Zoology, 108(1), 21-36.

Shackleton, C. M., Griffin, N. J., Banks, D. I., Mavrandonis, J. M., \& Shackleton, S. E. (1994). Community structure and species composition along a disturbance gradient in a communally managed South African savanna. Vegetatio, 115(2), 157-167.

Shannon, C. E., \& Wiener, W. (1963). The mathematical theory of communication, Champaign, Illinois, USA: University of Illinois Press.

Sheil, D., \& Burslem, D. F. R. P. (2003). Disturbing hypotheses in tropical forests. Trends in Ecology and Evolution, 18(1), 18-26. https://doi.org/ 10.1016/S0169-5347(02)00005-8

Shrestha, K. B., Måren, I. E., Arneberg, E., Sah, J. P., \& Vetaas, O. R. (2013). Effect of anthropogenic disturbance on plant species diversity in oak forests in Nepal, central Himalaya. International Journal of Biodiversity Science, Ecosystem Services and Management, 9(1), 21-29. https://doi. org/10.1080/21513732.2012.749303

Simpson, E. H. (1949). Measurement of diversity. Nature, 163, 688.

Singh, S., Malik, Z. A., \& Sharma, C. M. (2016). Tree species richness, diversity, and regeneration status in different oak (Quercus spp.) dominated forests of Garhwal Himalaya, India. Journal of Asia-Pacific Biodiversity, 9(3), 293-300. https://doi.org/10.1016/j.japb.2016.06.002

Smit, G. N. (2005). Tree thinning as an option to increase herbaceous yield of an encroached semi-arid savanna in South Africa. BMC Ecology, 5(4), 1-15. https://doi.org/10.1186/1472-6785-5-4

Soldati, G. T., de-Medeiros, P. M., Duque-Brasil, R., Coelho, F. M. G., \& Albuquerque, U. P. (2017). How do people select plants for use? Matching the ecological Apparency hypothesis with optimal foraging theory. Environment, Development and Sustainability, 19, 2143-2161. https://doi.org/10.1007/s10668-016-9844-1

SPSS Inc. (2017). IBM SPSS Statistics for Windows (No. 25). IBM Corp.

Stocking, M. (2001). Land degradation. In N. J. Smelser \& P. B. Baltes (Eds.), International encyclopedia of the Social \& Behavioral Sciences, Amsterdam, Netherland: Elsevier.

Strohbach, B. J. (2000). Vegetation degradation trends in the northern Oshikoto region: III. The Terminalia Prunioides Woodlands and Andoni Grasslands. Dinteria, 26, 77-92. http://www.nbri.org.na/sites/ default/files/Dinteria26E.pdf.

Symstad, A. J., \& Jonas, J. L. (2011). Incorporating biodiversity into rangeland health: Plant species richness and diversity in great plains grasslands. Rangeland Ecology and Management, 64(6), 555-572. https:// doi.org/10.2111/REM-D-10-00136.1

Tedder, M. J., Kirkman, K. P., Morris, C. D., Trollope, W. S. W., \& Bonyongo, M. C. (2012). The influence of Pechuel-Loeschea leubnitziae (wild sage) on grass sward and soil seed bank composition. African Journal of Range and Forage Science, 29(3), 101-107. https:// doi.org/10.2989/10220119.2012.720280

Tesfa, A., \& Mekuriaw, S. (2014). The effect of land degradation on farm size dynamics and crop-livestock farming system in Ethiopia: A review. Open Journal of Soil Science, 4, 1-5. https://doi.org/10.4236/ojss. 2014.41001.

Tews, J., Schurr, F., \& Jeltsch, F. (2004). Seed dispersal by cattle may cause shrub encroachment of Grewia flava on southern Kalahari rangelands. 
Applied Vegetation Science, 7(1), 89-102. https://doi.org/10.1111/j. 1654-109X.2004.tb00599.x

Tiwari, G. P., Tadele, K., Aramde, F., \& Tiwari, S. (2010). Community structure and regeneration potential of Shorea robusta Forest in subtropical submontane zone of Garhwal Himalaya, India. Nature and Science, 8(1), 70-74.

United Nations Convention to Combat Desertification. (2009). Climate change in the African drylands: Options and opportunities for adaptation and mitigation, New York: UNDP; Bonn, DE: UNCCD; Nairobi: UNEP: UNON Publishing Services. https://portals.iucn.org/library/sites/ library/files/documents/Bios-Eco-Ter-Ar-6-013.pdf.

USDA (1998). Soil quality information sheets. In Soil quality indicators: $\mathrm{pH}$ (p. 2). Washington, DC: USDA Forest Service. https://doi.org/10. 2136/sssaspecpub49.c25

Van-der-Hoeven, M., Osei, J., Greeff, M., Kruger, A., Faber, M., \& Smuts, C. M. (2013). Indigenous and traditional plants: South African parents' knowledge, perceptions and uses and their children's sensory acceptance. Journal of Ethnobiology and Ethnomedicine, 9, 78.

Vogt, J. V., Safriel, U., Von Maltitz, G., Sokona, Y., Zougmore, R., Bastin, G., \& Hill, J. (2011). Monitoring and assessment of land degradation and desertification: Towards new conceptual and integrated approaches. Land Degradation \& Development, 22(2), 150-165. https://doi.org/10.1002/ldr.1075

Wagner, T. C., Hane, S., Joubert, D. F., \& Fischer, C. (2016). Herbaceous legume encroachment reduces grass productivity and density in arid rangelands. PLoS One, 11(11), 1-13. https://doi.org/10.1371/journal. pone.0166743

Ward, D., Hoffman, M. T., \& Collocott, S. J. (2014). A century of woody plant encroachment in the dry Kimberley savanna of South Africa.
African Journal of Range and Forage Science, 31(2), 107-121. https:// doi.org/10.2989/10220119.2014.914974

Wigley, B. J., Bond, W. J., \& Hoffman, M. T. (2009). Bush encroachment under three contrasting land-use practices in a Mesic South African savanna. African Journal of Ecology, 47(SUPPL. 1), 62-70. https://doi. org/10.1111/j.1365-2028.2008.01051.x

Xue, Z., \& An, S. (2018). Changes in soil organic carbon and Total nitrogen at a small watershed scale as the result of land use conversion on the Loess Plateau. Sustainability, 10(12), 4757. https://doi.org/10.3390/ su10124757

Zarekia, S., Jafari, M., Arzani, H., Javadi, S. A., \& Jafari, A. A. (2012). Grazing effects on some of the physical and chemical properties of soil. World Applied Sciences Journal, 20(2), 205-212. https://doi.org/10.5829/ idosi.wasj.2012.20.02.1624

\section{SUPPORTING INFORMATION}

Additional supporting information may be found online in the Supporting Information section at the end of this article.

How to cite this article: Inman EN, Hobbs RJ, Tsvuura Z, Valentine L. Current vegetation structure and composition of woody species in community-derived categories of land degradation in a semiarid rangeland in Kunene region, Namibia. Land Degrad Dev. 2020;31:2996-3013. https://doi. org/10.1002/ldr.3688 